\title{
The Platelet ATP and ADP Receptors
}

\author{
C. Oury, E. Toth-Zsamboki, J. Vermylen and M.F. Hoylaerts*
}

Center for Molecular and Vascular Biology, University of Leuven, Leuven, Belgium

\begin{abstract}
Adenine nucleotides, ADP and ATP, are coreleased from dense granules during platelet activation, as well as from endothelial cells and damaged red blood cells following vascular injury. Through autocrine and paracrine mechanisms, these extracellular signaling molecules interact with the platelet $\mathrm{P} 2$ receptors to amplify ongoing platelet activation. Two receptors for ADP, the $\mathrm{G}_{\mathrm{q}}$-protein-coupled P2 $\mathrm{Y}_{1}$ and $\mathrm{G}_{\mathrm{i}}$-protein-coupled P2 $\mathrm{Y}_{12}$ and one receptor for ATP, the P2X ion channel, have been identified on platelets. Due to distinct pharmacological properties and differential regulation, the P2Y and P2X receptors essentially operate on different scales of time and distance and trigger selective intracellular signaling cascades. Recent advances in the understanding of the P2Y receptor physiology have reinforced the concept of these receptors as useful targets for antithrombotic therapy. The function of $\mathrm{P} 2 \mathrm{X}_{1}$ in platelet activation only recently started to be unraveled. This review focuses on recent findings on the physiology of these platelet ADP and ATP receptors, their distinct downstream intracellular signaling pathways as well as on the available agonists, antagonists and inhibitors that allow their pharmacological discrimination.
\end{abstract}

Key Words: Hemostasis, thrombosis, adenine nucleotides, $\mathrm{P} 2 \mathrm{Y}_{1}, \mathrm{P}_{2} \mathrm{Y}_{12}, \mathrm{P} 2 \mathrm{X}_{1}$, antithrombotic therapy.

\section{HISTORY AND CLASSIFICATION OF PURINERGIC RECEPTORS}

The first report about the potent actions of an adenine compound, AMP, extracted from heart muscle, was published by Drury and Szent-Györgyi in 1929. Initial investigations focused on effects of adenosine and ATP on the heart and vasculature, or concerned the effects of purines on platelets [1] and on mast cells. Further insights into the physiological role of extracellular purines and pyrimidines were provided via the study of their biological sources [2]. In this respect, the detection of nucleotide release from the heart during hypoxia [3] or from skeletal muscle during contraction indicated that secretion of purine compounds might be coupled to metabolic demand to regulate local blood flow. ATP release from sensory nerves suggested that adenine nucleotides play a role as neurotransmitter or neuromodulator in the central and peripheral nervous system [4].

These early publications established that purinergic nucleotides act as extracellular signaling molecules [5]. Nucleotides are now documented to contribute to a diverse range of physiological responses such as smooth muscle contraction, neurotransmission, exocrine and endocrine secretion, immune response, inflammation, platelet aggregation, male reproduction, nociception and modulation of cardiac function [6].

Purines and pyrimidines mediate their effects by interacting with distinct cell-surface receptors. Purinergic receptors were first formally recognized by Burnstock in 1978 [7]. They were divided into two classes: at P1-purinoceptors adenosine is the principal natural ligand, while P2-purinoceptors recognize both purine and pyrimidine nucleotides

\footnotetext{
*Address correspondence to this author at the Center for Molecular and Vascular Biology, University of Leuven, Herestraat 49, B-3000 Leuven; Tel: 3216 346145; Fax: 3216 345990;

E-mail: marc.hoylaerts@med.kuleuven.ac.be
}

[8], namely ATP, ADP, UTP and UDP. P1 receptors are further divided into four subtypes (A1, A2A, A2B, A3) and all couple to $\mathrm{G}$ proteins [9].

Based on an increasing amount of experimental data concerning signal transduction mechanisms, pharmacological response profiles, desensitization kinetics, tissue distribution and biological effects obtained during the 80-90s, the extensive and heterogeneous group of $\mathrm{P} 2$ receptors was subdivided into P2X ligand-gated cation channels and G proteincoupled P2Y receptors [10]. This classification was based almost exclusively on the potency of purine and pyrimidine nucleotides to act as P2 agonists, but it is now known to coincide with the molecular structure and signal transduction mechanism of the underlying receptors, and has been retained.

The possible pitfalls of agonist-based receptor classification are well known and are very relevant to the $\mathrm{P} 2$ receptor area. Errors can occur because many nucleotides are metabolically unstable and are degraded by the ecto-nucleotidases present on cells [6]. In addition, ectonucleoside-diphosphokinases on many cells can convert dinucleotides into trinucleotides, making assessment of ADP and UDP activities difficult [11]. Release of endogenous nucleotides may also introduce problems, due to desensitization and downregulation of the $\mathrm{P} 2$ receptor-promoted signaling response [11]. Finally, the presence of contaminating nucleotides in commercial nucleotide sources can produce misleading effects on the observed drug selectivity profiles at $\mathrm{P} 2$ receptor subtypes $[12,13]$.

\section{THE PLATELET P2Y 1 AND P2Y 12 RECEPTORS FOR ADP}

\section{Intracellular Signaling Pathways}

ADP signaling is often required to complete platelet aggregation. It is released from dense granules in response to 
agonist stimulation and can synergize with other agonists to activate platelets $[14,15]$. ADP produces platelet shape change and induces platelet aggregation by converting the platelet fibrinogen receptor, integrin $\alpha_{\mathrm{II}} \beta_{3}$, to an active conformation. The ability of ADP to trigger secretion from platelets is controversial and may depend on the presence of $\mathrm{Ca}^{2+}$ in the medium [16].

Platelets possess at least two $\mathrm{P} 2 \mathrm{Y}$ receptors whose combined action is required for full activation and aggregation in response to ADP [17-23] (Fig. 1). One of these, $\mathrm{P}_{2} \mathrm{Y}_{1}$, is coupled to the heterotrimeric GTP-binding protein $\mathrm{G}_{\mathrm{q}}$ and to phospholipase $C$ - $\beta$ activation; it induces mobilization of cytoplasmic $\mathrm{Ca}^{2+}$ and mediates shape change followed by an initial wave of rapidly reversible aggregation. Whether it also leads to stimulation of Rho/Rho kinase via $\mathrm{G \alpha}_{12 / 13}$ is unclear [24]. Nevertheless, the study by Paul et al. [25] indicates that both $\mathrm{Ca}^{2+} /$ calmodulin-stimulated myosin light chain kinase and p160 Rho-associated coiled-coil-containing protein kinase independently contribute to ADP-induced myosin light chain phosphorylation and to platelet shape change, through $\mathrm{Ca}^{2+}$-sensitive and $\mathrm{Ca}^{2+}$-insensitive pathways, respectively. It was also described that $\mathrm{P}_{2} \mathrm{Y}_{1}$ mediates p38 mitogen-activated protein kinase (p38MAPK) activation, an event requiring an aspirin-sensitive cofactor [26]; however, the functional significance of this signaling cascade in platelets and the downstream target of this kinase are not known.

The other receptor, $\mathrm{P} 2 \mathrm{Y}_{12}$ [27], is negatively coupled to adenylyl cyclase through $G_{i}$; it mediates progressive and sustained platelet aggregation in the absence of shape change and plays an important role in the potentiation of secretion induced by several agonists via its interaction with released ADP. This process is independent of the formation of large aggregates and of thromboxane $\mathrm{A}_{2}$ synthesis [28, 29]. $\mathrm{P} 2 \mathrm{Y}_{12^{-}}$ mediated activation of the phosphoinositide 3-kinase (PI 3K) pathway contributes to stabilize thrombin-induced platelet aggregates [30], although thrombin and thrombin-related peptides can cause platelet aggregation independently of $\mathrm{G}_{\mathrm{i}}$ signaling [31]. The concurrent activation of the $G_{q}$ and $G_{i}$ pathways during full platelet aggregation is highlighted by the observation that normal aggregation responses to ADP can be restored in $\mathrm{P} 2 \mathrm{Y}_{12}$-deficient platelets by adrenaline, which is negatively coupled to adenylyl cyclase through $G_{z}$ [32]; likewise, serotonin, which is coupled to $\mathrm{G}_{\mathrm{q}}$, can substitute for ADP in $\mathrm{P}_{2} \mathrm{Y}_{1}$-null mouse platelets [33, 34]. However, from studies performed on $\mathrm{G} \alpha_{\mathrm{q}}$-deficient murine platelets, it appeared that the activation of $\mathrm{G}_{12} / \mathrm{G}_{13^{-}}$and $\mathrm{G}_{\mathrm{i}^{-}}$ mediated pathways by the thromboxane $A_{2}$ mimetic and ADP, respectively, is sufficient to induce $\alpha_{\text {IIb }} \beta_{3}$ activation [35]. This indicates that the efficient induction of platelet aggregation through G-protein-coupled receptors is an integrated response triggered by various converging G-proteinmediated signaling pathways involving $G_{q}, G_{i}$ as well as $\mathrm{G}_{12} / \mathrm{G}_{13}$. Of interest is the observation that high ADP concentrations are able to induce partial $\alpha_{\mathrm{II}} \beta_{3}$-dependent aggregation without shape change for $\mathrm{P} 2 \mathrm{Y}_{1}$-null mouse platelets, through P2Y 12 -mediated PI 3-K activation [36]. Such aggregation was strongly potentiated by adrenaline.

The small GTPase Rap1B is activated by ADP through both $\mathrm{G}_{\mathrm{i}^{-}}$and PI 3-K-dependent and $\mathrm{G}_{\mathrm{q}^{-}}$and $\mathrm{Ca}^{2+}$-dependent mechanisms, which eventually may promote $\alpha_{\mathrm{IIb}} \beta_{3}$ activation
[37]. In this respect, Larson et al. [38] have recently shown that the collagen receptor GPVI-mediated Rap1 activation largely depended on ADP signaling through $\mathrm{P} 2 \mathrm{Y}_{12}$, but not through $\mathrm{P}_{2} \mathrm{Y}_{1}$. In the same context, another study showed that, during thromboxane $\mathrm{A}_{2}$ mimetic-induced platelet aggregation, signaling through the $\mathrm{P} 2 \mathrm{Y}_{12}$ receptor by secreted ADP causes positive feedback on platelet secretion through a PI-3 kinase pathway [39]. Thus, P2 $\mathrm{Y}_{12}$-mediated PI 3-K activation seems to be instrumental during platelet aggregation triggered by most platelet agonists (Fig. 1). Finally, a recent study shows an essential role for $\mathrm{P} 2 \mathrm{Y}_{12} / \mathrm{Gi}$ signaling pathways, via secreted ADP, in activating the PI 3-K-dependent serine-threonine kinase Akt during platelet responses to thrombin, PAR1- or PAR4-activating peptides [40].

\section{Pharmacology}

The order of potency for agonist stimulation of $\mathrm{P}_{2} \mathrm{Y}_{1}$ is 2 methyl-thio-ADP (2MeS-ADP) $\gg \mathrm{ADP}=\mathrm{ADP} \alpha \mathrm{S}>$ $\mathrm{ADP} \beta \mathrm{S}$ and of $\mathrm{P} 2 \mathrm{Y}_{12}$ is $2 \mathrm{MeS}-\mathrm{ADP} \gg \mathrm{ADP}=\mathrm{ADP} \beta \mathrm{S}$; $\mathrm{ADP} \alpha \mathrm{S}$ is an antagonist at $\mathrm{P} 2 \mathrm{Y}_{12}$. Structure-activity studies have previously been reviewed extensively [14, 41]. ADP receptor numbers have been quantified with radiolabeled 2MeS-ADP, which binds to between 500 and 1000 sites per platelet [29, 42-44]. Evaluation of $\mathrm{P} 2 \mathrm{Y}_{1}$ binding sites is enabled by studies performed under conditions in which one receptor is blocked or absent. In the two well-characterized patients lacking $\mathrm{P} 2 \mathrm{Y}_{12}$, the number of $2 \mathrm{MeS}$-ADP binding sites fell to about 30 for one patient [42] and to about 170 for the other [43]. These low values fit with the difficulties to detect $\mathrm{P} 2 \mathrm{Y}_{1}$ in flow cytometry by using available antibodies; in the $\mathrm{P}_{2} \mathrm{Y}_{12}$-deficient SP1999 mouse model, no specific binding for $2 \mathrm{MeS}-\mathrm{ADP}$ could be measured [45]. In fact, a recent study [46] described the existence of internal membrane pools of $\mathrm{P} 2 \mathrm{Y}_{1}$ receptors, on membranes of $\alpha$-granules and of the open canalicular system (OCS), and on a network of thin channels that ramify from the surface into the interior of the platelet. Although the functional significance of the internal pools is unknown, pharmacological antagonism of ADP during antithrombotic therapy may need to take into account blockade of such internal receptor pools.

Platelets treated with ADP $\beta$ S become refractory to ADP stimulation [47]; this platelet refractory state was entirely due to desensitization of the $\mathrm{P} 2 \mathrm{Y}_{1}$ receptor, the $\mathrm{P} 2 \mathrm{Y}_{12}$ receptor remaining functional. The decrease in $\left[{ }^{33} \mathrm{P}\right] 2$ MeSADP binding sites measured on refractory platelets corresponded to the disappearance of the $\mathrm{P} 2 \mathrm{Y}_{1}$ sites with no change in the number of $\mathrm{P} 2 \mathrm{Y}_{12}$ sites, suggesting internalization of $\mathrm{P} 2 \mathrm{Y}_{1}$. This was confirmed by flow cytometric analysis of Jurkat cells expressing an epitope-tagged $\mathrm{P} 2 \mathrm{Y}_{1}$ receptor, where ADP $\beta S$ treatment resulted in complete loss of the receptor from the cell surface. It was concluded that the $\mathrm{P}_{2} \mathrm{Y}_{1}$ and $\mathrm{P} 2 \mathrm{Y}_{12}$ receptors are differently regulated during platelet activation.

\section{The P2Y 1 Receptor}

The $\mathrm{P} 2 \mathrm{Y}_{1}$ receptor was the first $\mathrm{P} 2 \mathrm{Y}$ to be cloned and identified as a metabotropic receptor for adenine nucleotides [47]. Since its discovery, many more P2Y receptor subtypes have been identified [48] and the current series now extends to $\mathrm{P}_{2} \mathrm{Y}_{13}$ [49]. $\mathrm{P} 2 \mathrm{Y}_{1}$ couples to heterotrimeric $\mathrm{G}$ proteins $\left(\mathrm{G}_{\mathrm{q}} / \mathrm{G} \alpha_{11}\right)$ and, through this link, stimulates phospho- 
inositide turnover and release of intracellular calcium. Human $\mathrm{P}_{2} \mathrm{Y}_{1}$ is particularly sensitive to ADP and 2MeS-ADP; whether ATP is an agonist of $\mathrm{P}_{2} \mathrm{Y}_{1}$ is highly controversial and may depend on receptor expression levels. The tissue distribution for $\mathrm{P} 2 \mathrm{Y}_{1}$ protein, and messenger RNA, is ubiquitous -found in peripheral sensory nerves and central nervous system, most physiological systems and many cell types including blood platelets. P2 $\mathrm{Y}_{1}$-deficient mice [33, 34] displayed impaired platelet aggregation and increased resistance to pulmonary thromboembolism induced by infusion of a mixture of collagen and adrenaline. Also, using tissue factor (TF) to promote thrombin dependent thromboembolism, these mice exhibited higher thromboresistance and a significantly reduced in vivo thrombin generation [51]. These observations have led the authors to present the platelet $\mathrm{P} 2 \mathrm{Y}_{1}$ receptor as a potential target for antithrombotic therapy.

The 2-Chloro- $\mathrm{N}^{6}$-methyl- $(N)$-methanocarba-2' deoxyadenosine-3', 5'-biphosphate (MRS 2279) developed in the Molecular Recognition Section (NIH, Bethesda, MD) is a potent highly selective and competitive antagonist for the $\mathrm{P}_{2} \mathrm{Y}_{1}$ receptor with a $K_{\mathrm{d}}$ value of $9 \mathrm{nM}$ at the platelet receptor $[52,53]$. This antagonist provides the means to study the physiological role of native $\mathrm{P}_{2} \mathrm{Y}_{1}$ receptors. MRS 2279 potently inhibits ADP-induced aggregation of human platelets in vitro, although the current utility of the compound is limited to being a research tool, not an antithrombotic agent. The origins of this compound can be traced back to work on the inhibitory actions of simple bisphosphate nucleotides (e.g. adenosine 3'-phosphate 5'-phosphate) at the $\mathrm{P} 2 \mathrm{Y}_{1}$ receptor - where these agents acted as competitive, yet not especially potent, antagonists [54]. Others drew attention to the "limited subtype specificity and non-P2 receptor effects" of such bisphosphate nucleotides $[55,56]$. The next landmark compound was MRS 2179 ( $\mathrm{N}^{6}$-methyl 2'-deoxyadenosine 3', 5'-biphosphate), another competitive antagonist at the $\mathrm{P}_{2} \mathrm{Y}_{1}$ receptor [57-60]. But hopes for MRS2179 were dashed following observations of inhibitory activity for this compound at recombinant $\mathrm{P} 2 \mathrm{X}_{1}$ and $\mathrm{P} 2 \mathrm{X}_{3}$ receptors [61]. Thereafter, the focus switched to non-ribose compounds

\section{Ticlopidine}

Clopidogrel

AR-C69931MX

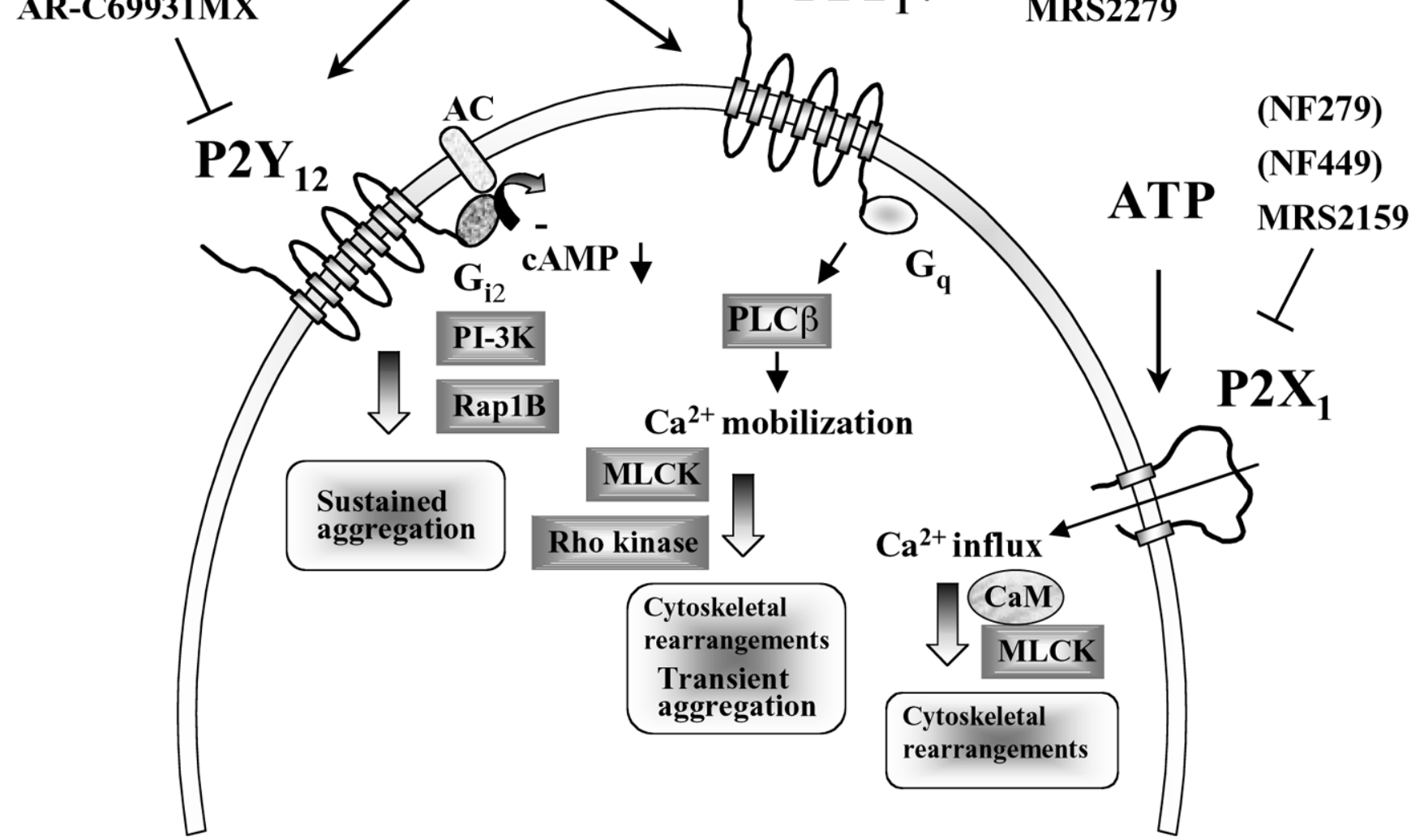

ADP

Fig. (1). Current model of platelet purinergic receptors. Two receptors for ADP, $P 2 Y_{1}$ coupled to $G_{q}$ and $P 2 Y_{12}$ coupled to $G_{i}$, and one receptor for ATP, the $\mathrm{P} 2 \mathrm{X}_{1}$ ion channel, contribute to platelet activation. Inhibitors or antagonists of $\mathrm{P}_{2} \mathrm{Y}_{12}$ are useful antithrombotic drugs. Selective $\mathrm{P}_{2} \mathrm{Y}_{1}$ antagonists that inhibit platelet function in vitro also exist. Compounds acting as selective and highly potent antagonists at the recombinant $\mathrm{P} 2 \mathrm{X}_{1}$ receptor are shown. Whether these compounds are able to inhibit $\mathrm{P} 2 \mathrm{X}_{1}$-dependent events in platelets largely remains to be investigated. Nothing is known on the ability of NF279 and NF449 to antagonize the platelet $\mathrm{P}_{2} \mathrm{X}_{1}$ receptor. 
where the ribose moiety was substituted by methanocarba pseudosugars in either Northern $(\mathrm{N})$ or Southern $(\mathrm{S})$ conformations - to reduce the flexibility of the sugar spacer and enhance ligand docking. The resultant MRS 2279 represents the most potent and selective compound of this series of analogues, as reported by Boyer et al. [52]. Full understanding of the pharmacology of MRS 2279 will depend on its commercial availability. As yet, MRS 2279 has not been tested on recombinant $\mathrm{P} 2 \mathrm{X}$ receptors. Also, no mention is made of its (in)activity at adenosine receptors. The chemical structures of these $\mathrm{P} 2 \mathrm{Y}_{1}$ antagonists have been presented in a recent review [15].

\section{The P2Y 12 Receptor}

In contrast to the ubiquitous expression of $\mathrm{P}_{2} \mathrm{Y}_{1}$ [62], $\mathrm{P} 2 \mathrm{Y}_{12}$ expression is restricted to platelets and the brain [27, 63]. The intronless genes for $\mathrm{P} 2 \mathrm{Y}_{1}$ and $\mathrm{P} 2 \mathrm{Y}_{12}$ receptors are co-localized on chromosome 3q21-q25 [64] and share $22 \%$ sequence identity [27, 62]. $\mathrm{P}_{2} \mathrm{Y}_{12}$ is the therapeutic target of ticlopidine and clopidogrel, two platelet aggregation inhibitors used for prevention and treatment of arterial thrombosis $[65,66]$. Clopidogrel (SR25990C, PLAVIX) is a potent antiaggregant and antithrombotic drug, as demonstrated in several experimental models of thrombosis [67]. The drug was launched on the market following a successful clinical evaluation and demonstration of superior efficacy versus aspirin in preventing thrombotic events (myocardial infarction, stroke, and vascular death) in high risk patients (CAPRIE Steering Committee, 1996). Clopidogrel administered in vivo selectively and irreversibly inhibits the binding of $2 \mathrm{MeS}-\mathrm{ADP}$ to platelet $\mathrm{P}_{2} \mathrm{Y}_{12}$ [68-70]. Clopidogrel is inactive in vitro and has to undergo metabolic activation by hepatic cytochrome P450-1A [71, 72]. A possible metabolic pathway leading to the formation of the active metabolite of clopidogrel was tentatively deduced [73]. In the liver, clopidogrel is metabolized into 2-oxo-clopidogrel. This intermediate is then hydrolyzed and generates the highly labile active metabolite, which reacts as a thiol reagent with $\mathrm{P} 2 \mathrm{Y}_{12}$ on platelets when they pass the liver. This in situ biological effect could account for the absence of an antiaggregating activity in the plasma. In a recent work [74], the occurence of an in vitro active metabolite was documented after incubation of 2-oxo-clopidogrel with human liver microsomes. Mass spectrometry results suggested that the active metabolite belongs to a family of eight stereoisomers with the following primary chemical structure: 2-\{1-[1-(2-chlorophenyl)-2-methoxy-2-oxoethyl]-4-sulfanyl-3-piperidinylidene $\}$ acetic acid. However, only one of the eight metabolites retained biological activity, underlining the critical importance of the associated absolute chemical configuration. The active metabolite would be of $\mathrm{S}$ configuration at $\mathrm{C} 7$ and $\mathrm{Z}$ configuration at the $\mathrm{C} 3-\mathrm{C} 16$ double bond.

The active metabolite of clopidogrel, containing a free thiol group, inactivates $\mathrm{P} 2 \mathrm{Y}_{12}$ through formation of a disulfide bridge with extracellular cysteine residues [69, 73, 75]. Another antiplatelet drug, CS-747, neutralizes $\mathrm{P}_{2} \mathrm{Y}_{12}$ by the same mechanism $[76,77]$. $\mathrm{P}_{2} \mathrm{Y}_{12}$ also is irreversibly antagonized by the thiol reagent pCMBS $[69,78]$. By using sitedirected mutagenesis analysis, Ding et al. [79] have identified two free cysteine residues in the $\mathrm{P} 2 \mathrm{Y}_{12}$ extracellular domain ( $\mathrm{C} 17$ and $\mathrm{C} 270)$ to be the targets for thiol reagents.
They proposed that the lack of these free cysteines in the extracellular domain of $\mathrm{P}_{2} \mathrm{Y}_{1}$ explains why this receptor is not inhibited by thiol reagents and by the active metabolites of clopidogrel or by CS-747.

Since ticlopidine and clopidogrel are prodrugs requiring metabolization, inhibition of platelet aggregation by these drugs is delayed until $24-48 \mathrm{~h}$ after administration, with maximal inhibition achieved after 3-5 days [65]. Recovery of platelet function after drug withdrawal is slow (7-14 days). Ticlopidine and clopidogrel are effective in preventing atherothrombotic events in cardiovascular, cerebrovascular and peripheral vascular disease. However, neutropenia and thrombotic thrombocytopenic purpura are significant and occasionally fatal adverse effects of ticlopidine. Clopidogrel appears to offer several advantages over ticlopidine: a more rapid onset of action and lower incidence of the adverse effects. A combination of clopidogrel and aspirin has become standard antithrombotic therapy in a few cardiovascular conditions (e.g. following stent placement). The pharmacology and clinical developments of the thienopyridine derivatives have been recently reviewed [65].

Competitive $\mathrm{P}_{2} \mathrm{Y}_{12}$ antagonists are also being developed $[80,81]$. Modification of the polyphosphate side chain of ATP to prevent breakdown to ADP and substitution of the adenine moiety to enhance affinity and selectivity for the $\mathrm{P} 2 \mathrm{Y}_{12}$ receptor led to the identification of 2-propylthio- $\beta, \gamma$ dichloromethylene ATP (AR-C67085MX) [80], having an $\mathrm{IC}_{50}$ of $2.5 \mathrm{nM}$ against ADP-induced aggregation of human platelets. This compound was the first very potent competitive antagonist of the $\mathrm{P} 2 \mathrm{Y}_{12}$ receptor, with a selectivity for that subtype of the P2 receptor family of $>1000$-fold. Further modification of the structure produced $N^{6}$-(2-methylthioethyl)-2-(3, 3, 3-trifluoropropylthio)- $\beta, \gamma$-dichloromethylene ATP (AR-C69931MX) with an $\mathrm{IC}_{50}$ of $0.4 \mathrm{nM}$ [80]. In a canine model of arterial thrombosis, AR-C69931MX was found to antagonize the ex vivo and in vivo aggregatory actions of ADP, and to display a rapid onset and offset of action with the ability to prevent occlusive arterial thrombus formation [82]. This compound also sustains canine coronary artery recanalization and improves myocardial tissue perfusion [83]. It therefore may be suited for the management of patients who require short-term modulation of platelet function. AR-C69931MX currently is in phase II clinical trials for the treatment of acute coronary syndromes.

Chemical stuctures of the $\mathrm{P} 2 \mathrm{Y}_{12}$ antagonists and inhibitors are depicted in the recent review by Gachet [15].

\section{Congenital Defects of $\mathrm{P}_{2} \mathrm{Y}_{12}$}

Congenital deficiency of $\mathrm{P} 2 \mathrm{Y}_{12}$ results in a bleeding disorder. Four patients with abnormalities of platelet function due to a severe defect of $\mathrm{P} 2 \mathrm{Y}_{12}$ have been described so far $[29,42,84,85]$. In common, these patients have a lifelong history of mucosal bleeding, easy bruising and/or excessive post-operative bleeding, mildly to severely prolonged bleeding times, weak and rapidly reversible primary wave of aggregation induced by ADP and abnormalities of platelet aggregation induced by collagen, arachidonate and thromboxane $A_{2}$ analogues, but normal aggregation induced by high concentrations of thrombin. Platelets deficient for this receptor exhibit normal ADP-induced shape change but ADP 
fails to inhibit the rise in cAMP levels after stimulation with prostaglandin $\mathrm{E}_{1}$ [86]. The $\mathrm{P}_{2} \mathrm{Y}_{12}$ defect is inherited as a autosomal recessive trait [86], and heterozygous patients display a mild abnormality in platelet function similar to that seen in the relatively common primary secretion defects.

The genetics of $\mathrm{P} 2 \mathrm{Y}_{12}$ defects have been investigated. In two instances, different homozygous frameshift mutations were found to cause premature termination of translation. In another case, one allele presented a reading frame shift caused by the deletion of two nucleotides, whereas the other case had a normal coding sequence but a reduced expression, possibly resulting from another mutation in a regulatory region of the gene [27]. In a recent report [85], the patient was a compound heterozygote for two distinct amino acid substitutions that independently impair all the responses mediated by $\mathrm{P} 2 \mathrm{Y}_{12}$ without affecting ADP binding.

\section{Role of the ADP Receptors in Coagulation}

While the ADP pathway is recognized to enhance thrombus formation by recruiting platelets and leukocytes to the primary layer of collagen-adhering platelets, its role for the initiation of coagulation has not been revealed.

The platelet $\mathrm{P} 2 \mathrm{Y}_{1}$ and $\mathrm{P} 2 \mathrm{Y}_{12}$ receptors both contribute to thrombosis and thrombin formation in an in vivo model of TF-induced thromboembolism [51]. The $\mathrm{P}_{2} \mathrm{Y}_{12}$ receptor, but not $\mathrm{P} 2 \mathrm{Y}_{1}$, was also found to be involved in thrombin-induced exposure of phosphatidylserine on isolated platelets and in TF-induced thrombin formation in platelet-rich-plasma [87]. Both receptors contribute to the interaction between platelets and leukocytes mediated by P-selectin exposure, and resulting TF exposure at the surface of leukocytes [87].

A recent study [88] shows that ex vivo inhibition of the $\mathrm{P}_{2} \mathrm{Y}_{12}$ ADP receptor by clopidogrel administration diminished the rapid exposure of TF in conjugates of platelets with leukocytes established by the contact of whole blood with fibrillar collagen. In in vitro conditions, the $\mathrm{P} 2 \mathrm{Y}_{12}$ and $\mathrm{P} 2 \mathrm{Y}_{1}$ ADP receptors were both found to be implicated in the exposure of TF in collagen-activated whole blood. Immunoelectron-microscopy revealed that collagen elicited the release of TF from its storage pools within the platelets. Functional activation of the intravascular TF was reduced by inhibition of the ADP receptors, partially due to the disruption of the platelet-neutrophil adhesions. Injection of collagen into the venous circulation of mice increased the number of thrombin-antithrombin complexes, indicative for the formation of thrombin in vivo. In $\mathrm{P}_{2} \mathrm{Y}_{1}$-deficient mice, the ability of collagen to enhance the generation of thrombin was impaired. This study indicate that the platelet ADP pathway supports the initiation of intravascular coagulation, which is likely to contribute to the concomitant formation of fibrin at the site of the growing thrombus.

\section{THE PLATELET P2X 1 RECEPTOR FOR ATP}

\section{The Family of P2X Receptors}

Seven distinct $\mathrm{P} 2 \mathrm{X}$ subunits $\left(\mathrm{P} 2 \mathrm{X}_{1}-\mathrm{P} 2 \mathrm{X}_{7}\right)$ assemble to form homo- or heteromeric non-selective ATP-gated cation channels composed of at least 3 monomers; these have been cloned from mammalian cell types and characterized pharmacologically by patch clamp electrophysiological meas- urements in heterologous expression systems [reviewed in $89,90]$. Their overall characteristics and functional properties closely resemble those in native tissues.

The pharmacological and biophysical properties allow the receptors to be classified into three groups, which correspond in broad terms to the three phenotypes described for the native receptors.

The first group comprises the $\mathrm{P} 2 \mathrm{X}_{1}$ and $\mathrm{P} 2 \mathrm{X}_{3}$ receptors; they are both highly responsive to the specific, nonhydrolyzable, stable P2X analogue, $\alpha, \beta-$ meATP as well as to ATP, and their desensitization is rapid $\left(\mathrm{P} 2 \mathrm{X}_{1}\right.$ has a time constant of about 100 to $300 \mathrm{~ms}, \mathrm{P}_{2} \mathrm{X}_{3}$ desensitization is best fit by two exponentials of about $50 \mathrm{~ms}$ and $1 \mathrm{~s}$ ).

The second group comprises the $\mathrm{P} 2 \mathrm{X}_{2}, \mathrm{P} 2 \mathrm{X}_{4}, \mathrm{P} 2 \mathrm{X}_{5}$, and $\mathrm{P} 2 \mathrm{X}_{6}$ receptors. In all these cases, $\alpha, \beta-$ meATP is ineffective and the receptor desensitization rate is slow. These receptors can be further subdivided according to their antagonist sensitivity: $\mathrm{P} 2 \mathrm{X}_{2}$ and $\mathrm{P} 2 \mathrm{X}_{5}$ receptors are reversibly inhibited by PPADS and suramin $(<30 \mu \mathrm{M})$ (Fig. 2), while P2X $\mathrm{X}_{4}$ and $\mathrm{P}_{2} \mathrm{X}_{6}$ receptors are not blocked by this concentration of PPADS and suramin.

The third distinct type of functional response is exhibited by the $\mathrm{P} 2 \mathrm{X}_{7}$ receptor. It has a 240 amino acid longer intracellular $\mathrm{C}$-terminus than other $\mathrm{P} 2 \mathrm{X}$ receptors. $\mathrm{P} 2 \mathrm{X}_{7}$, cloned from rat macrophages and brain, is the cytolytic $\mathrm{P} 2$ receptor previously described in mast cells, fibroblasts and macrophages. Receptor distribution is generally limited to hemopoietic bone marrow cells including granulocytes, monocytes, macrophages, B-lymphocytes, erythrocytes and erythroleukemia cells. The unique feature of cloned and endogenous $\mathrm{P}_{2} \mathrm{X}_{7}$-like receptors is that, whereas under physiological conditions they are selectively permeable only to small cations, in the continued presence of ATP and when divalent cation levels are low, the cation channel can convert to a pore, that is permeable to larger molecules upto 900 daltons in addition to ions. This effect is associated with cytotoxicity. Currents evoked at recombinant $\mathrm{P}_{2} \mathrm{X}_{7}$ and endogenous $\mathrm{P} 2 \mathrm{X}_{7}$-like receptors do not readily desensitize.

\section{Subunit Topology}

Although the three-dimensional structure of the P2X subunits is not known, the absence of a leader sequence and their hydrophobicity pattern predict that they have two transmembrane domains, placing a large protein loop outside the cell [91] (Fig. 1).

The different P2X subunits vary between 379 and 595 amino acids in length and share an overall sequence identity ranging from $35 \%$ to $48 \%$. The extracellular loop of $\mathrm{P} 2 \mathrm{X}$ channels is highly glycosylated; in the $\mathrm{P} 2 \mathrm{X}_{2}$ channel, glycosylation occurs at three asparagine residues (N182, N239 and N298) and deletion of any two out of the three leads to nonfunctional channels [92].

Based on structural similarities with the mechanosensitive channels of the MscL class, the amino- and carboxyterminal tails of $\mathrm{P} 2 \mathrm{X}$ subunits might be close to each other, sitting beneath the channel pore in a closed state. This stoichiometry may explain how truncations, deletions, mutations and splicing in these regions greatly affect the kinetics, permeation and desensitization of the channels [90]. In 


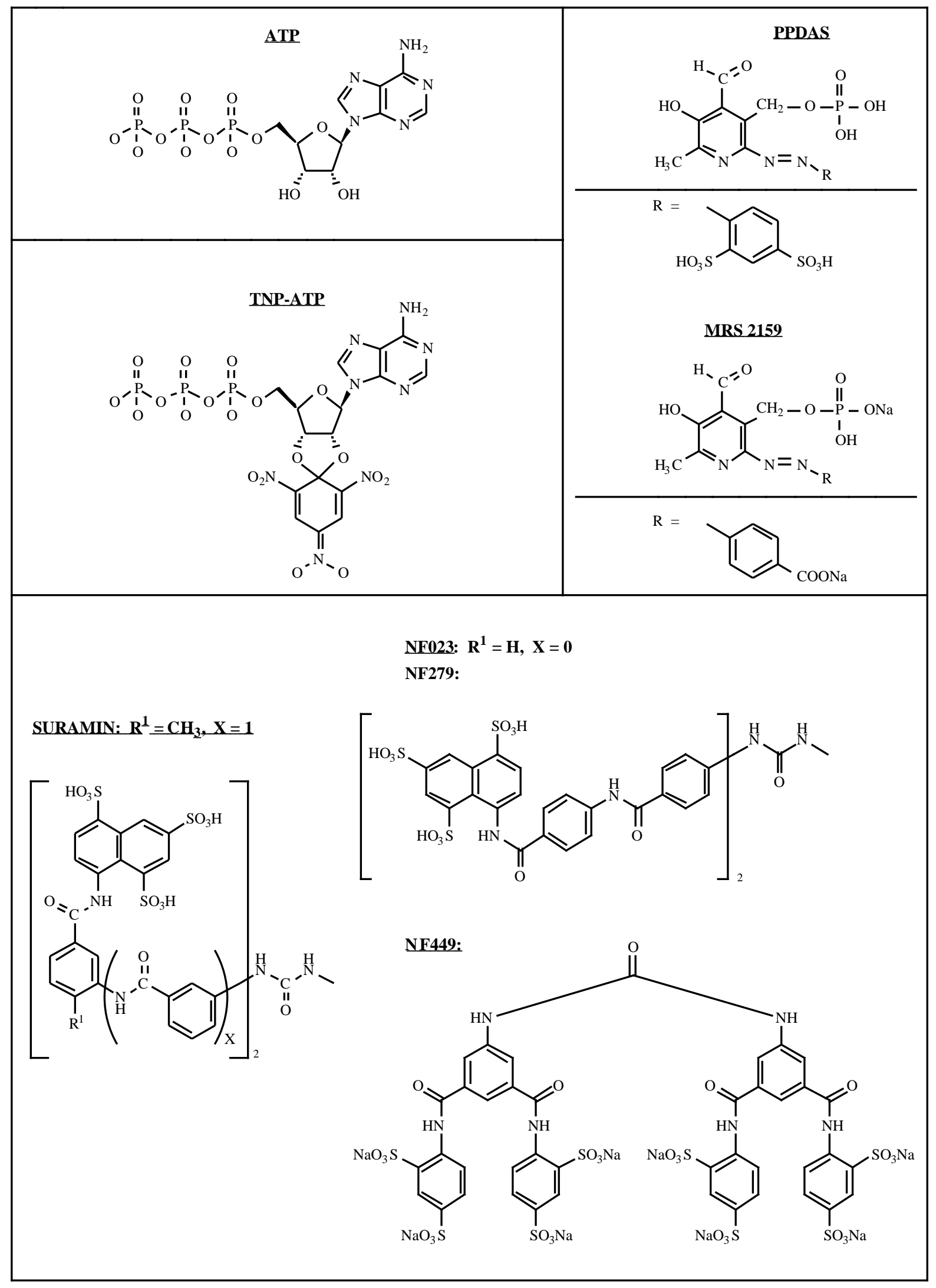

Fig. (2). Chemical structures of selective antagonists of the recombinant $\mathrm{P}_{2} \mathrm{X}_{1}$ receptor. 
addition, these intracellular regions are clearly important, but not the sole determinants of receptor function, as expected for allosteric proteins. The possibility that the long carboxy tail of $\mathrm{P} 2 \mathrm{X}$ receptors interacts with other proteins has been suggested; interaction of $\mathrm{P}_{2} \mathrm{X}_{7}$ channels with several cytoskeletal proteins has been demonstrated [93].

Using disulfide bond formation between engineered cysteines, a recent study demonstrated close proximity between the outer ends of the first transmembrane domain of one subunit and the second transmembrane domain of another [94]. In the hetero-oligomeric $\mathrm{P} 2 \mathrm{X}_{2} / \mathrm{P} 2 \mathrm{X}_{3}$ receptor, the coexpression in HEK293 cells of doubly substituted subunits with wild-type partners revealed that the hetero-oligomeric channel contains adjacent $\mathrm{P} 2 \mathrm{X}_{3}$ subunits but does not contain adjacent $\mathrm{P} 2 \mathrm{X}_{2}$ subunits. This study suggests a "head-to-tail" subunit arragement in the quaternary structure of $\mathrm{P} 2 \mathrm{X}$ receptors and show that a trimeric $\mathrm{P} 2 \mathrm{X}_{2} / \mathrm{P} 2 \mathrm{X}_{3}$ receptor would have the composition $\mathrm{P} 2 \mathrm{X}_{2}\left(\mathrm{P} 2 \mathrm{X}_{3}\right)_{2}$.

The ATP-binding site of $\mathrm{P} 2 \mathrm{X}$ receptors is thought to be located within the cysteine-rich extracellular loop, because ATP gates P2X receptors when applied extracellularly. In addition, purified extracellular loops obtained from $\mathrm{P}_{2} \mathrm{X}_{2}$ subunits bind ATP [95]. P2X receptors do not contain consensus motifs common to other ATP-binding proteins. Interestingly, alterations in ATP potency were easily produced by mutagenesis of many residues [90]. Systematic analyses of the extracellular loop indicate that positively charged residues (K68 and K70, R292 and K309) in this region form part of the channel vestibule and contribute to the binding of the terminal phosphate of ATP in P2X subunits [96]. Accordingly, a recent study in Xenopus oocytes revealed that among the 20 conserved aromatic amino acids located in the extracellular ligand binding loop of $\mathrm{P} 2 \mathrm{X}_{1}$, residues $\mathrm{K} 68$, F185, F291, R292 and K309 contribute to ligand binding, with F185 and F291 co-ordinating the binding of the adenine ring of ATP [97].

Combined mutagenesis and pharmacological studies have suggested that the non-specific P2 antagonist PPADS binds to the same site as ATP, whereas other classes of P2 antagonists, like suramin, have a different binding site within the extracellular loop [98, 99] (Fig. 2). These observations indicate that other binding sites in addition to the ATP site exist, modulate receptor function and probably might be targeted selectively with different drugs.

\section{Desensitization of P2X Receptors}

$\mathrm{P} 2 \mathrm{X}$ receptors were divided into two broad groups according to current desensitization i.e. returning to zero rapidly (within 100 to $300 \mathrm{~ms}$ ), or slowly if at all. The rapid desensitization of the ion currents should not be confused with receptor "desensitization", which occurs over a few seconds and reflects the inability of the receptor to respond to subsequent agonist application. Desensitization clearly serves to terminate the purinergic response even though ATP still is present in the environment.

The molecular mechanism of $\mathrm{P} 2 \mathrm{X}$ receptor desensitization is not well understood. For the rapidly desensitizing $\mathrm{P} 2 \mathrm{X}_{1}$ receptor, this may involve the hydrophobic domains of the receptor because in $\mathrm{P} 2 \mathrm{X}_{1}-\mathrm{P} 2 \mathrm{X}_{2}$ chimeras, transfer of the
$\mathrm{P} 2 \mathrm{X}_{1}$ hydrophobic domains, but not the extracellular loop of the $\mathrm{P} 2 \mathrm{X}_{1}$ receptor changes the phenotype of the $\mathrm{P} 2 \mathrm{X}_{2}$ receptor from non-desensitizing to rapidly-desensitizing [100]. Accordingly, a $\mathrm{P} 2 \mathrm{X}_{1}-\mathrm{P} 2 \mathrm{X}_{2}$ chimera containing the entire $\mathrm{P}_{2} \mathrm{X}_{1}$ extracellular domain shows the non-desensitizing property of $\mathrm{P} 2 \mathrm{X}_{2}$ [101]. The $\mathrm{N}$-terminal region of the $\mathrm{P} 2 \mathrm{X}_{3}$ receptor has been suggested to be important in the desensitization process. Desensitization of the $\mathrm{P} 2 \mathrm{X}_{3}$ receptor seems to involve the activation of calcineurin through the entry of extracellular calcium [102].

\section{Regulation of Channel Function}

Similarly to other neurotransmitter-gated channels, prolonged agonist stimulation results in changes in the surface localization of $\mathrm{P} 2 \mathrm{X}$ receptors. $\mathrm{P} 2 \mathrm{X}_{1}$ receptors tagged with green fluorescent protein are rapidly internalized following agonist stimulation [103]; native $\mathrm{P}_{2} \mathrm{X}_{1}$ receptors were also internalized in smooth muscle [104]. However, this phenomenon, probably involving cytosolic factors, does not explain the rapidly desensitizing phenotype of the $\mathrm{P} 2 \mathrm{X}_{1^{-}}$ mediated currents. It remains to be determined whether other P2X receptors are similarly internalized and how this mechanism affects the regulation of $\mathrm{P} 2 \mathrm{X}$ receptor-mediated responses in native cells.

All P2X subunits contain a consensus protein kinase $\mathrm{C}$ (PKC) phosphorylation site (Thr-X-Lys/Arg) in the aminoterminal tail. PKC-mediated threonine phosphorylation was shown to preserve the slowly desensitising property of the $\mathrm{P} 2 \mathrm{X}_{2}$ channel [105]. Disruption of this residue leads to $\mathrm{ab}-$ sent phosphorylation of the protein and simultaneously converts the ion current to the rapidly desensitizing phenotype. The same Thr residue is essential in $\mathrm{P}_{2} \mathrm{X}_{3}$ channel function since, when replaced by Ala, the channel became inactive. Moreover, this site has been shown to be responsible for the PKC-mediated potentiating effect of inflammatory mediators on $\mathrm{P} 2 \mathrm{X}_{3}$ channel function, probably explaining the ability of these mediators to modulate nociception [106]. In transfected HEK293 cells, the absence of $\mathrm{P}_{2} \mathrm{X}_{1}$ phosphorylation on residue T18 abolishes the ATP-induced inward current. Moreover, mutating residue R20 into T20 leads to absence of phosphorylation on residue T18 [107]. A recent study reported that in the slowly-desensitizing $\mathrm{P}_{2} \mathrm{X}_{7}$ channel, phosphorylation of a single tyrosine residue at position 343 is required to maintain the run-down of the current as well as to sustain the interaction of $\mathrm{P}^{2} \mathrm{X}_{7}$ with several, mainly cytoskeletal proteins, resulting in formation of a signaling complex [94]. These observations suggest that phosphorylation of the conserved PKC site serves as effective regulator of the channel function.

Using site-directed mutagenesis, we have investigated the function of the four highly conserved intracellular tyrosine residues of the $\mathrm{P}^{2} \mathrm{X}_{1}$ ion channel [108] (Fig. 3). Simultaneous electrophysiological and calcium measurements in transfected human embryonic kidney (HEK293) cells indicated that Y362F and Y370F mutants were non-functional, despite their proper plasma membrane expression. The Y16F and Y363F mutants retained $2.2 \%$ and $26 \%$ of the wild-type $\mathrm{P} 2 \mathrm{X}_{1}$ activity, respectively. However, no tyrosine phosphorylation was detected on Western blots of $\mathrm{P} 2 \mathrm{X}_{1}$ immunoprecipitates derived either from HEK293 cell lysates or from 

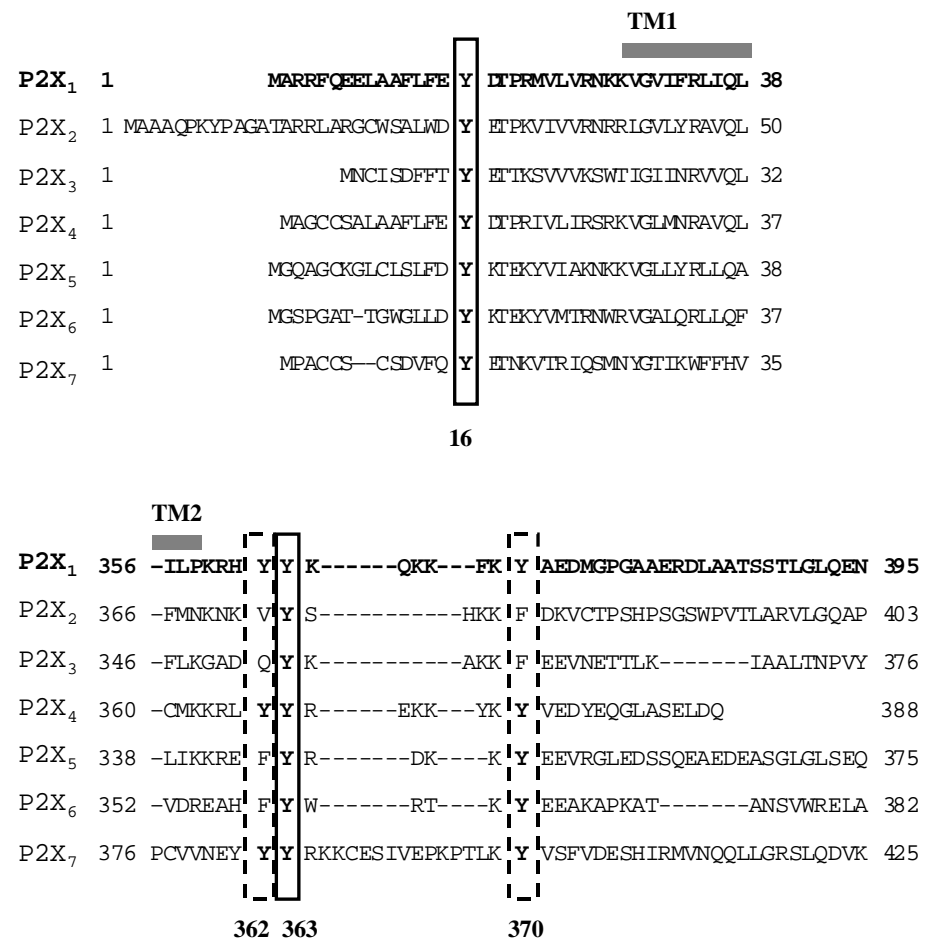

Fig. (3). Sequence alignment of human P2X receptors. Conserved tyrosine residues are boxed with solid lines and partially conserved residues with dashed lines. P2 $\mathrm{X}_{1}$ transmembrane domains (TM1 and TM2) are overlined with a bar.

human platelets, with or without stimulation of the receptor. Thus, we concluded that Y16, Y362, Y363, and Y370 are required for the appropriate three-dimensional structure and function of the intracellular $\mathrm{P} 2 \mathrm{X}_{1}$ domains, independently of their phosphorylation.

Extracellular cations modulate ATP-activated currents in cloned and endogenous $\mathrm{P} 2 \mathrm{X}$ receptors. $\mathrm{Mg}^{2+}$ and $\mathrm{Ca}^{2+}$ generally inhibit $\mathrm{P} 2 \mathrm{X}$ receptor currents, probably by decreasing the affinity of the ATP binding site via an allosteric modulation in the receptor. Interestingly, the recombinant $\mathrm{P} 2 \mathrm{X}_{1}$ receptor seems to be less susceptible to inhibition by increases in extracellular $\mathrm{Ca}^{2+}$ [109]; $\mathrm{Zn}^{2+}$ potentiates the cation conductance induced by ATP at most $\mathrm{P} 2 \mathrm{X}$ receptors, including recombinant $\mathrm{P} 2 \mathrm{X}_{1}$.

Modulation of the affinity of the ATP-binding site also occurs by extracellular protons; acid $\mathrm{pH}$ causes an increase, and alkaline $\mathrm{pH}$ causes a decrease in currents [110]. This may be particularly significant for $\mathrm{P} 2 \mathrm{X}$ receptor-mediated signaling in pathophysiological conditions where injury or inflammation can alter the extracellular $\mathrm{pH}$.

\section{The P2X $\mathrm{X}_{1}$ Receptor}

The $\mathrm{P} 2 \mathrm{X}_{1}$ receptor has been first cloned from rat vas deferens and human and mouse urinary bladder [111, 112]. The $\mathrm{P} 2 \mathrm{X}_{1}$ receptor encoding gene contains 12 exons spanning 20 kilobases on chromosome $17 \mathrm{p} 13.2 . \mathrm{P}_{2} \mathrm{X}_{1}$ receptor mRNA is expressed in urinary bladder, vas deferens, smooth muscle layers of small arteries and arterioles, with lower levels in spinal cord and rat brain, in lung and spleen and finally in dorsal root, trigeminal and coeliac ganglia [90,
111]. There is a prominent variation in the size of transcripts expressed in different tissues. The regulatory processes underlying tissue specific expression of the $\mathrm{P}_{2} \mathrm{X}_{1}$ gene are unknown except for an $\mathrm{E}$ box response element that binds a $\beta$ helix-loop-helix protein and contributes to smooth muscle specific transcriptional regulation [113].

\section{Pharmacology}

The recombinant receptor is activated by 2 MeSATP $\geq$ ATP $>\alpha, \beta-$ meATP, and inward currents evoked by these compounds are reversibly blocked by suramin, PPADS [110] and are very sensitive to inhibition by TNP-ATP $\left(\mathrm{IC}_{50}\right.$ about $1 \mathrm{nM}$ ) [114] (Fig. 2). Suramin analogues showing selectivity for $\mathrm{P} 2 \mathrm{X}_{1}$ receptors have been synthetized and characterized pharmacologically: one such compound is the symmetrical 3'-urea of 8-(benzamido)naphtalene-1, 3, 5-trisulfonate (NF023) [115] (Fig. 2). NF023 is wholy selective for $\mathrm{P}_{2} \mathrm{X}_{1}$ receptors in studies with the cloned receptor expressed in Xenopus oocytes, being weak at recombinant $\mathrm{P} 2 \mathrm{Y}_{1}\left(\mathrm{pIC}_{50}=\right.$ 4.6). A series of second generation suramin analogues with 4'-aminobenzoyl-linkages of one or two phenyl rings have been evaluated. One of these compounds, NF279, was the subject of a more detailed pharmacological investigation [116]. In prostatic segments of the rat vas deferens, NF279 (0.3-3 $\mu \mathrm{M})$ inhibited the contractions evoked by $\alpha, \beta$ meATP. A physiological role for $\mathrm{P}_{2} \mathrm{X}_{1}$ receptors in renal microvascular autoregulatory behavior has been described [117]. Afferent arterioles from rats and $\mathrm{P} 2 \mathrm{X}_{1}$-deficient mice (see below) were examined using the juxtamedullary nephron technique. Pressure-mediated vasoconstriction were measured before or during $\mathrm{P} 2 \mathrm{X}_{1}$ receptor blockade with 
NF279. This compound as well as deletion of $\mathrm{P} 2 \mathrm{X}_{1}$ receptors attenuated the autoregulatory response induced by an increase in renal perfusion pressure. NF279 was also a highly potent $\mathrm{P} 2 \mathrm{X}_{1}$-selective antagonist $\left(\mathrm{IC}_{50}=0.02-0.05 \mu \mathrm{M}\right)$ in studies with cloned receptors expressed in Xenopus oocytes [118]. This compound was found to be weak at recombinant $\mathrm{P}_{2} \mathrm{Y}_{1}\left(\mathrm{pIC}_{50}=4.6\right)$ and inactive (up to $\left.100 \mu \mathrm{M}\right)$ at $\mathrm{P}_{2} \mathrm{Y}_{2}$, $\mathrm{P}_{2} \mathrm{Y}_{4}$, and $\mathrm{P} 2 \mathrm{Y}_{6}$ receptors.

The antagonistic effects of the novel suramin analogue 4, 4', 4", 4"'-(carbonylbis(imino-5, 1, 3-benzenetriylbis(carbonylimino)))tetrakis-benzene-1, 3-disulfonic acid (NF449) [119] (Fig. 2) were analyzed at homomeric human $\mathrm{P} 2 \mathrm{X}_{1}$ and $\mathrm{P}_{2} \mathrm{X}_{7}$ receptor subtypes $\left(\mathrm{hP} 2 \mathrm{X}_{1}\right.$ and $\mathrm{h} \mathrm{P} 2 \mathrm{X}_{7}$ ) heterologously expressed in Xenopus oocytes using the two-microelectrode voltage-clamp technique. At activating ATP concentrations of 1 microM $\left(\mathrm{hP} 2 \mathrm{X}_{1}\right)$ and 100 microM $\left(\mathrm{hP} 2 \mathrm{X}_{7}\right), \mathrm{IC}_{50}$ values of $0.05 \mathrm{nM}$ and $40 \mu \mathrm{M}$ were found for $\mathrm{hP} 2 \mathrm{X}_{1}$ and $\mathrm{hP} 2 \mathrm{X}_{7}$ receptors, respectively. The Schild analysis revealed a $\mathrm{pA}_{2}$ of 10.7 at $\mathrm{hP} 2 \mathrm{X}_{1}$. Wash-in and wash-out of $10 \mathrm{nM} \mathrm{NF} 449$ were nearly complete within $16 \mathrm{~s}$ and 4 min, respectively, at the $\mathrm{hP} 2 \mathrm{X}_{1}$ receptor. An increase in the activating ATP concentration to 100 microM shifted the NF449 concentrationinhibition curve rightwards for the $\mathrm{hP}_{2} \mathrm{X}_{1}$ receptor. NF449 decelerated activation as well as desensitization of $\mathrm{hP} 2 \mathrm{X}_{1}$. It is concluded that NF449 acts as a reversible competitive antagonist at the $\mathrm{hP} 2 \mathrm{X}_{1}$ with much higher potency at $\mathrm{hP} 2 \mathrm{X}_{1}$ than at $\mathrm{hP} 2 \mathrm{X}_{7}$ receptors. NF449 may hence be excellently suited to discriminate between both receptors in native human tissues.

Novel analogues of PPADS have also been developed and characterized as antagonists at recombinant $\mathrm{P} 2 \mathrm{X}_{1}, \mathrm{P} 2 \mathrm{X}_{2}$, and $\mathrm{P} 2 \mathrm{X}_{3}$ receptors in Xenopus oocytes and turkey erythrocyte $\mathrm{P}_{2} \mathrm{Y}_{1}$ receptors [120]. From these studies, the compound MRS2159 was found to be a very potent and selective $\mathrm{P}_{2} \mathrm{X}_{1}$ antagonist $\left(\mathrm{IC}_{50}=10 \mathrm{nM}\right)$ (Fig. 2).

L- $\beta, \gamma$-meATP proved to be a useful agonist to distinguish $\mathrm{P} 2 \mathrm{X}_{1}$ from other $\mathrm{P} 2 \mathrm{X}$ receptors. It is a potent agonist at recombinant $\mathrm{P}_{2} \mathrm{X}_{1}\left(\mathrm{EC}_{50}=1.9 \mu \mathrm{M}\right)$ [121] and induces contraction of a variety of smooth muscle preparations via $\mathrm{P}_{2} \mathrm{X}_{1^{-}}$ like receptors [122]. In contrast, L- $\beta, \gamma$-meATP has been found to be ineffective at recombinant $\mathrm{P} 2 \mathrm{X}_{2}[121]$ and $\mathrm{P} 2 \mathrm{X}_{4}$ receptors and at native $\mathrm{P} 2 \mathrm{X}$ receptors in $\alpha, \beta-$ meATPresponding and non-responding neurons. Furthermore, L$\beta, \gamma$-meATP is inactive on $\mathrm{P} 2 \mathrm{Y}$ receptors mediating relaxant responses in guinea-pig taenia coli and on native and recombinant $\mathrm{P} 2 \mathrm{Y}$ receptors from chick brain. It is also resistant to degradation by ecto-nucleotidases, and its potential breakdown product, $\mathrm{L}-$ adenosine, is inactive at $\mathrm{P} 1$ receptors.

Activation and desensitization kinetics of the rat $\mathrm{P} 2 \mathrm{X}_{1}$ receptor at nanomolar ATP concentrations were further studied in Xenopus oocytes using two-electrode voltageclamp recording [123]. The authors propose that these low ATP concentrations obscure $\mathrm{P} 2 \mathrm{X}_{1}$ receptor responses by driving a significant fraction of the receptor pool into a longlasting refractory closed state. The $\mathrm{K}_{1 / 2}$ of $3.2 \mathrm{nM}$ for receptor desensitization would reflect the nanomolar ATP affinity of the receptor found by others in agonist binding experiments. The high $\mathrm{EC}_{50}$ value of $0.7 \mu \mathrm{M}$ for receptor activation is a consequence of fast desensitization combined with non- steady-state conditions during recording of peak currents, which are the basis of the dose-response curve.

In order to study the intrinsic $\mathrm{P}_{2} \mathrm{X}_{1}$ receptor kinetics, the same authors have used a non-desensitizing $\mathrm{P} 2 \mathrm{X}_{1} / \mathrm{P} 2 \mathrm{X}_{2}$ chimera comprising the entire $\mathrm{P} 2 \mathrm{X}_{1}$ ectodomain [118]. This chimera showed a 200- and 7000-fold higher ATP potency than observed for parent $\mathrm{P}_{2} \mathrm{X}_{1}$ and $\mathrm{P} 2 \mathrm{X}_{2}(\mathrm{~A})$ receptors, respectively. Upon washout, the chimera deactivated slowly with a time constant $\mathrm{t}$ inversely related to the $\mathrm{EC}_{50}$ value of the corresponding agonist tested, suggesting that deactivation time courses reflect unbinding rates. The chimera also possesses virtually identical sensitivity to NF279. Thus, in agreement with the previous work, this study shows that the P2 $\mathrm{X}_{1}$ ectodomain confers nanomolar ATP sensitivity, which within the wild type receptor is obscured by desensitization such that only a micromolar ATP potency can deduced from peak current measurements, representing an amalgam of activation and desensitization.

\section{P2X 1 -Null Mice}

The gene for mouse $\mathrm{P} 2 \mathrm{X}_{1}$ was cloned and its genomic structure defined by sequencing [124]. The gene spans about $10 \mathrm{~kb}$ and consists of 12 exons. All splice sites conformed to the GT-AG motif and the exon-intron boundaries were largely conserved with other members of the P2X gene family so far cloned. A single transcription-starting site was identified by 5' RACE analysis, 233 bp upstream of the translation start site. The $\mathrm{P}_{2} \mathrm{X}_{1}$ gene maps to the central region of mouse chromosome 11 .

$\mathrm{P} 2 \mathrm{X}_{1}$-deficient mice show reduced male fertility to approximately $90 \%$ [125]. Male mice copulate normally reduced fertility results from a reduction of sperm in the ejaculate and not from sperm dysfunction. In these mice, contraction of the vas deferens to sympathetic nerve stimulation is reduced by up to $60 \%$ and responses to $\mathrm{P} 2 \mathrm{X}$ receptor agonists are abolished. These results show that $\mathrm{P} 2 \mathrm{X}_{1}$ receptors are essential for normal male reproductive function.

$\mathrm{P} 2 \mathrm{X}$ receptor mediated inward currents and contractions are abolished in bladder smooth muscle from $\mathrm{P} 2 \mathrm{X}_{1}$-deficient mice [126]. In normal bladder nerve stimulation evoked contractions with $\mathrm{P} 2 \mathrm{X}$ and muscarinic acetylcholine (mACh) receptor mediated components. In bladder from the $\mathrm{P}_{2} \mathrm{X}_{1}$ deficient mouse the contraction was mediated solely by $\mathrm{mACh}$ receptors. These results indicate that homomeric $\mathrm{P} 2 \mathrm{X}_{1}$ receptors underlie the bladder smooth muscle $\mathrm{P} 2 \mathrm{X}$ receptor phenotype. This animal model also revealed that homomeric $\mathrm{P}_{2} \mathrm{X}_{1}$ receptors underlie the artery smooth muscle $\mathrm{P} 2 \mathrm{X}$ receptor phenotype and contribute approximately $50 \%$ to sympathetic neurogenic vasoconstriction of mouse mesenteric arteries [127]. However, from a study examining the distribution, ontogeny and role of $\mathrm{P} 2 \mathrm{X}_{1}$ receptors in the smooth muscle of the mouse intestine, bladder, and male and female reproductive tracts, it appeared that $\mathrm{P} 2 \mathrm{X}_{1}$ receptors are not expressed throughout all smooth muscles and that their expression is developmentally regulated [128]. So, $\alpha, \beta-$ meATP (100 microM) failed to evoke contractions of the epididymis, or seminal vesicle and $\mathrm{P} 2 \mathrm{X}_{1}$ receptors did not contribute to the control of uterine smooth muscle. In contrast, in the ileum, $\alpha, \beta$-meATP (100 microM) evoked a tran- 
sient relaxation followed by a contraction. These responses were abolished by the P2 receptor antagonist iso-pyridoxalphosphate-6-azophenyl-2'-5'-disulphonate (iso-PPADS) (30 microM). Accordingly, contractile responses were reduced by $>80 \%$ in the ileum from $\mathrm{P} 2 \mathrm{x} 1$ receptor-deficient mice.

The use of $\mathrm{P} 2 \mathrm{X}_{1}$-null mice also showed that $\mathrm{P} 2 \mathrm{X}_{1}$ subunits contribute to the properties of heteromeric $\mathrm{P} 2 \mathrm{X}$ receptors in sympathetic neurons [129]. Finally, tubuloglomerular feedback signals are coupled to autoregulatory preglomerular vasoconstriction through ATP-mediated activation of $\mathrm{P} 2 \mathrm{X}_{1}$ receptors [117].

\section{The Platelet P2X 1 Receptor for ATP}

Following molecular identification of $\mathrm{P} 2 \mathrm{X}_{1}$ as the first known P2X subunit from rat vas deferens [111], the $\mathrm{P} 2 \mathrm{X}_{1}$ cDNA was also cloned from human platelets and megakaryoblastic cell lines [130]. The use of P2X-based degenerated primers led to the amplification of a single band of cDNA from human platelet RNA preparations as well as from three megakaryoblastic cell lines (Meg-01, K562, and CMK11-5). Subsequent DNA sequencing confirmed that this fragment was identical to a region of cloned human urinary bladder smooth muscle $\mathrm{P}_{2} \mathrm{X}_{1}$ receptor. Importantly, no additional homologous clones were obtained, indicating that in platelets only $\mathrm{P} 2 \mathrm{X}_{1}$ subunits are expressed, forming rapidly desensitizing non-selective homomeric cation channels. Western blotting of platelet lysates separated by SDS-PAGE and probed with anti-P2 $\mathrm{X}_{1} \mathrm{IgG}$ reveals the expected protein with a molecular mass of $60 \mathrm{kDa}$ under reducing or nonreducing conditions. Endoglycosidase treatment results in altered migration, the reduced protein weight of $45 \mathrm{kDa}$ confirms the highly glycosylated nature of the mature protein [131].

Interestingly, even before molecular cloning of the receptor, its existence in platelets had been anticipated by patch clamp techniques and intracellular calcium measurements. Several studies indicated that the extremely rapid kinetics of ADP- and ATP-mediated increase in intracellular $\mathrm{Ca}^{2+}$ concentration were consistent with direct opening of a plasma membrane ion channel in human platelets [132, 133]. More recently, it was specified that ADP/ATP activates a non-selective inward cation current, which does not involve a diffusible second messenger. It had also been demonstrated that the ADP/ATP-gated non-selective cation channel resembles a P2X-type purinoceptor, since the selective P2Xagonist $\alpha, \beta-$ meATP activated rapidly desensitizing, nonselective cation currents in human platelets. Similarly to platelets, in rat megakaryocytes ATP and the stable, nonselective ATP-analogue ATP $\gamma \mathrm{S}$ activated a rapid, nonselective cation channel, consistent with P2X-type responses [134, 135]. Interestingly, spontaneously activated single channel currents in platelets were similar to P2X currents, suggesting both to be caused by autocrine activation following release of endogenous nucleotides. The transient, non-selective P2Xtype current under physiological ionic conditions seemed to be carried mostly by $\mathrm{Na}^{+}$, although $\mathrm{P} 2 \mathrm{X}_{1}$ receptors exhibit five fold selectivity for $\mathrm{Ca}^{2+}$ over $\mathrm{Na}^{+}[111,135]$.

The $\mathrm{P} 2 \mathrm{X}_{1}$ receptor was initially thought to be an ADP/ATP-activated ion channel and therefore to contribute to platelet responses to ADP. However, this proposal did not fit with the findings that P2Y-mediated $G_{q}$ and $G_{i}$ protein activation were sufficient to support ADP-induced platelet aggregation, and that $\alpha, \beta-$ meATP did not interfere with this platelet response, which brought doubts on the role of $\mathrm{P} 2 \mathrm{X}_{1}$ in platelet function. In view of the possible pitfalls and artefactual results arising from contaminating tri-phosphate nucleotides in commercially available di-phosphate nucleotide samples, the $\mathrm{P} 2 \mathrm{X}_{1}$ agonist profile was re-examined using HPLC-purified compounds. It appeared that $\mathrm{P} 2 \mathrm{X}_{1}$ receptortriggered ion currents in megakaryocytes were activated by $\alpha, \beta$-meATP and by commercially available ADP, while HPLC-purified ADP was inactive [136]. This observation has motivated further analyses of the platelet $\mathrm{P} 2 \mathrm{X}_{1}$ receptor as an ATP receptor, while ADP would act exclusively at $\mathrm{P}_{2} \mathrm{Y}_{1}$ and $\mathrm{P}_{2} \mathrm{Y}_{12}$ receptors. Using HPLC-purified nucleotides, we have further confirmed that ATP is the agonist of platelet $\mathrm{P} 2 \mathrm{X}_{1}$ receptors at which ADP acts as a weak antagonist [137]. Even though the issue of ADP versus ATP as a $\mathrm{P} 2 \mathrm{X}_{1}$-specific ligand was "reactivated" by the identification of an alternate $\mathrm{P} 2 \mathrm{X}_{1}$ receptor termed $\mathrm{P} 2 \mathrm{X}_{1 \text { del }}$ (lacking 17 amino acids in the extracellular domain) [138], clear and definitive evidence now exist that the $\mathrm{P} 2 \mathrm{X}_{1 \text { del }}$ receptor fails to form functional ion channels and is below the limit of detection in human platelets and that ATP is the sole $\mathrm{P}_{2} \mathrm{X}_{1}$ agonist $[139,140]$.

Estimations based on transient whole-cell currents indicated a channel density of only 14-34 per platelet [141]. Nevertheless, due to rapid desensitization, a proper evaluation of functional $\mathrm{P} 2 \mathrm{X}_{1}$ receptors is complicated. Immunoblot analysis suggests significant, high expression of the $\mathrm{P}_{2} \mathrm{X}_{1}$ protein, strongly maintained during megakaryocytic differentiation and platelet formation [131]. Study of $\left[{ }^{3} \mathrm{H}\right] \alpha, \beta-$ meATP binding on platelets showed only one type of binding site, its affinity being in the same order of magnitude compared to that reported for ATP receptors in rat bladder and vas deferens [142]. Scatchard analysis of the saturation binding data indicated that $\left[{ }^{3} \mathrm{H}\right] \alpha, \beta-$ meATP bound with high affinity $\left(K_{\mathrm{d}}=23.6 \mathrm{nM}\right)$. Compared to the binding of $\left[{ }^{3} \mathrm{H}\right] 2-\mathrm{MeS}-\mathrm{ATP}$, the number of $\mathrm{P} 2 \mathrm{X}_{1}$ receptors detected with $\left[{ }^{3} \mathrm{H}\right] \alpha, \beta$-meATP was 4 -fold higher, being evaluated at $4190 \pm 150$ sites per platelet. 2 -MeS-ADP and ADP competitively inhibited the specific binding of $\left[{ }^{3} \mathrm{H}\right] \alpha, \beta-$ meATP with $\mathrm{IC}_{50}$ values of 103 and $1120 \mathrm{nM}$, respectively.

Using $\mathrm{P} 2 \mathrm{X}_{1}$-deficient mouse platelets and megakaryocytes [143], the lack of $\alpha, \beta-$ meATP-induced $\mathrm{Ca}^{2+}$ responses was demonstrated, further confirming that the $\mathrm{P} 2 \mathrm{X}$ receptor phenotype in megakaryocytes and in platelets is due to expression of homomeric $\mathrm{P}_{2} \mathrm{X}_{1}$ receptors. Interestingly, coapplication in wild-type megakaryocytes of $\alpha, \beta-$ meATP and ADP resulted in acceleration and amplification of the peak $\mathrm{Ca}^{2+}$ response, implying a priming role for $\mathrm{P} 2 \mathrm{X}$ receptors in the subsequent activation of metabotropic P2Y receptors during platelet stimulation.

We have identified a clonal mutation in the platelet $\mathrm{P} 2 \mathrm{X}_{1}$ receptor of a patient showing a severe bleeding disorder [144]. This mutation results in deletion of one leucine residue contained in the second transmembrane (TM2) domain of this receptor. Voltage-clamped HEK293 cells 
expressing mutated $\mathrm{P} 2 \mathrm{X}_{1}$ channels failed to develop an ATPinduced current. Furthermore, when co-expressed with the wild type receptor in Xenopus oocytes, the mutated protein exhibited a dose-dependent dominant negative effect on the normal ATP-induced $\mathrm{P}_{2} \mathrm{X}_{1}$ channel activity. These data indicate that deletion of a single apolar amino acid residue at the inner border of the $\mathrm{P}_{2} \mathrm{X}_{1} \mathrm{TM} 2$ generates a non-functional channel. The platelet defect of this patient was characterized by defective platelet secretion and aggregation induced by low or intermediate doses of collagen, thromboxane $\mathrm{A}_{2}$ mimetic, and thrombin-related peptide; the ADP-induced platelet aggregation were also strongly impaired when analyzed in the presence of high extracellular $\mathrm{Ca}^{2+}$ concentrations (hirudinized-PRP). Despite of this, the P2 $\mathrm{Y}_{1}$ and P2Y 12 receptors were found to be normal. The molecular basis of the platelet defect and the causative link between the $\mathrm{P} 2 \mathrm{X}_{1}$ mutation and the bleeding phenotype are still unclear.

The two stable ATP analogs $\alpha, \beta$-meATP and L$\beta, \gamma$-meATP produce a $\mathrm{P} 2 \mathrm{X}_{1}$-mediated extracellular $\mathrm{Ca}^{2+}$ dependent quickly reversible platelet shape change [137, 145]. Recently, it was shown that, by increasing the extracellular $\mathrm{Ca}^{2+}$ concentration, the $\mathrm{P} 2 \mathrm{X}_{1}$-evoked light transmission decrease (a measure of shape change) reached $82 \%$ of that obtained via $\mathrm{P}_{2} \mathrm{Y}_{1}$ receptors [146]. Despite of this, following blockade of $\mathrm{P}_{2} \mathrm{Y}_{1}$ receptors with A3P5PS, costimulation with $\alpha, \beta$-meATP and ADP failed to induce aggregation. Therefore, it appears that the early $\mathrm{Ca}^{2+}$ influx via $\mathrm{P}_{2} \mathrm{X}_{1}$ does not readily synergise with $\mathrm{P}_{2} \mathrm{Y}_{12}$ to support aggregation. However, it has been shown that the $\mathrm{P}_{2} \mathrm{X}_{1}$ agonist $\alpha, \beta-$ meATP potentiates platelet microaggregate formation when added in conjunction with other weak platelet agonists such as epinephrine and thrombopoietin [147].

By using a selective $\mathrm{P} 2 \mathrm{X}_{1}$ desensitization strategy, we found that $\mathrm{P} 2 \mathrm{X}_{1}$ contributes to platelet aggregation induced by collagen [137]. The ionotropic $\mathrm{P} 2 \mathrm{X}$ receptors regulate intracellular calcium levels through the ligand-stimulated increase in calcium permeability. However, how these receptors are linked to intracellular signaling pathways subserving their biological actions still is poorly understood. We have described that stable $\mathrm{P}_{2} \mathrm{X}_{1}$ agonists elicit reversible extracellular signal-regulated kinase 2 (ERK2) phosphorylation through a $\mathrm{Ca}^{2+}$-and protein kinase $\mathrm{C}$-dependent pathway [148] (Fig. 4). Moreover, we have shown that ERK2 activation caused by low concentrations of collagen exclusively depends on the $\mathrm{P} 2 \mathrm{X}_{1}$-mediated $\mathrm{Ca}^{2+}$-influx through early ATP secretion evoked by this agonist. The P2X $\mathrm{X}_{1}$-PKC-ERK2 pathway plays a role in amplifying dense granule release, an event needed for completion of platelet aggregation upon mild stimulation with collagen. Furthermore, we found that $\alpha, \beta$-meATP causes rapid, transient $(2-5 \mathrm{~s})$, and dosedependent myosin light chain (MLC) phosphorylation [149]. Phosphorylation was inhibited by the calmodulin (CaM) inhibitor W-7, but not by the Rho kinase inhibitor HA-1077, i.e. it is exclusively regulated by $\mathrm{Ca}^{2+} / \mathrm{CaM}$-dependent MLC kinase. Correspondingly, the $\mathrm{P} 2 \mathrm{X}_{1}$-induced platelet shape change was inhibited by W-7 and by the MLC kinase inhibitor ML-7 but not by HA-1077. W-7, ML-7, the protein kinase C inhibitor GF109203-X, and the Src family kinase inhibitor PP1 inhibited the collagen and convulxin-induced early platelet degranulation, shape change, and subsequent aggregation, indicating a role for $\mathrm{Ca}^{2+} / \mathrm{CaM}$ and MLC kinase in these glycoprotein VI-related platelet responses. The secreted ATP-mediated $\mathrm{P}_{2} \mathrm{X}_{1}$-dependent ERK2 activation induced by low collagen concentrations contributes to MLC kinase activation since $\mathrm{P} 2 \mathrm{X}_{1}$ desensitization or blockade of ERK2 phosphorylation by U0126 strongly attenuated MLC phosphorylation, degranulation, and aggregation. We therefore conclude that at low doses of collagen, glycoprotein VI activation leads to early protein kinase C- and MLC kinasedependent degranulation. Rapidly released ATP triggers $\mathrm{P} 2 \mathrm{X}_{1}-$ mediated $\mathrm{Ca} 2+$ influx, activating ERK2, in turn amplifying platelet secretion by reinforcing the early MLC kinase phosphorylation. Hence, the $\mathrm{P}_{2} \mathrm{X}_{1}$-ERK2-MLC axis contributes to collagen-induced platelet activation by enhancing platelet degranulation (Fig. 4).

In order to investigate further the role of $\mathrm{P} 2 \mathrm{X}_{1}$ and the coupled ERK2 in hemostasis and thrombosis, we have generated transgenic mice overexpressing the human $\mathrm{P} 2 \mathrm{X}_{1}$ receptor in the megakaryocytic cell lineage [150]. Platelets from transgenic mice exhibited a gain of $\mathrm{P} 2 \mathrm{X}_{1}$ ionotropic activity as determined by more prominent $\mathrm{P} 2 \mathrm{X}_{1}$-mediated $\mathrm{Ca}^{2+}$ influx and platelet shape change. $\mathrm{P} 2 \mathrm{X}_{1}$ overexpression enhanced platelet secretion and aggregation evoked by low doses of collagen, convulxin, or the thromboxane $\mathrm{A}_{2} \mathrm{mi}-$ metic U46619. In contrast, transgenic platelet responses to ADP or thrombin were normal. Perfusing whole blood from transgenic mice over collagen fibers at a shear rate of $1000 \mathrm{~s}^{-}$ ${ }^{1}$ resulted in increased $\mathrm{P}_{2} \mathrm{X}_{1}$-dependent aggregate formation and phosphatidylserine exposure. Platelet hyperreactivity to collagen was correlated with upregulated extracellular signal-regulated kinase 2 (ERK2) phosphorylation. Accordingly, the MEK1/2 inhibitor U0126 potently inhibited the collagen-induced aggregation of transgenic platelets, either stirred or when perfused over a collagen surface. In a viscometer, shear stress caused potent aggregation of transgenic platelets in conditions where wild-type platelets did not aggregate. In an in vivo model of thromboembolism consisting of intravenous injection of a low dose of collagen plus adrenaline, transgenic mice died more readily than wild-type mice. Preinjection of U0126 not only fully protected transgenic mice against thrombosis, but also enhanced the survival of wild-type mice injected with a higher collagen dose.

In agreement with our findings, the analysis of $\mathrm{P} 2 \mathrm{X}_{1}$ deficient mouse platelets [151] showed decreased collageninduced aggregation and secretion; adhesion and thrombus growth on a collagen-coated surface was also reduced, particularly when the wall shear rate was elevated. The mortality of $\mathrm{P} 2 \mathrm{X}_{1}$-deficient mice in a model of systemic thromboembolism was reduced and the size of mural thrombi formed after a laser-induced vessel wall injury was decreased as compared with normal mice, whereas the time for complete thrombus removal was shortened.

Both studies $\left(\mathrm{P} 2 \mathrm{X}_{1}\right.$ overxpressing mice and $\mathrm{P} 2 \mathrm{X}_{1}$ deficient mice) thus indicate that the $\mathrm{P} 2 \mathrm{X}_{1}$ receptor contributes to the formation of platelet thrombi, particularly in conditions in which shear forces are high.

Owing to the lack of selective platelet $\mathrm{P} 2 \mathrm{X}_{1}$ antagonists and because of the rapid desensitization of this receptor during platelet preparation, it had been difficult to analyze the 


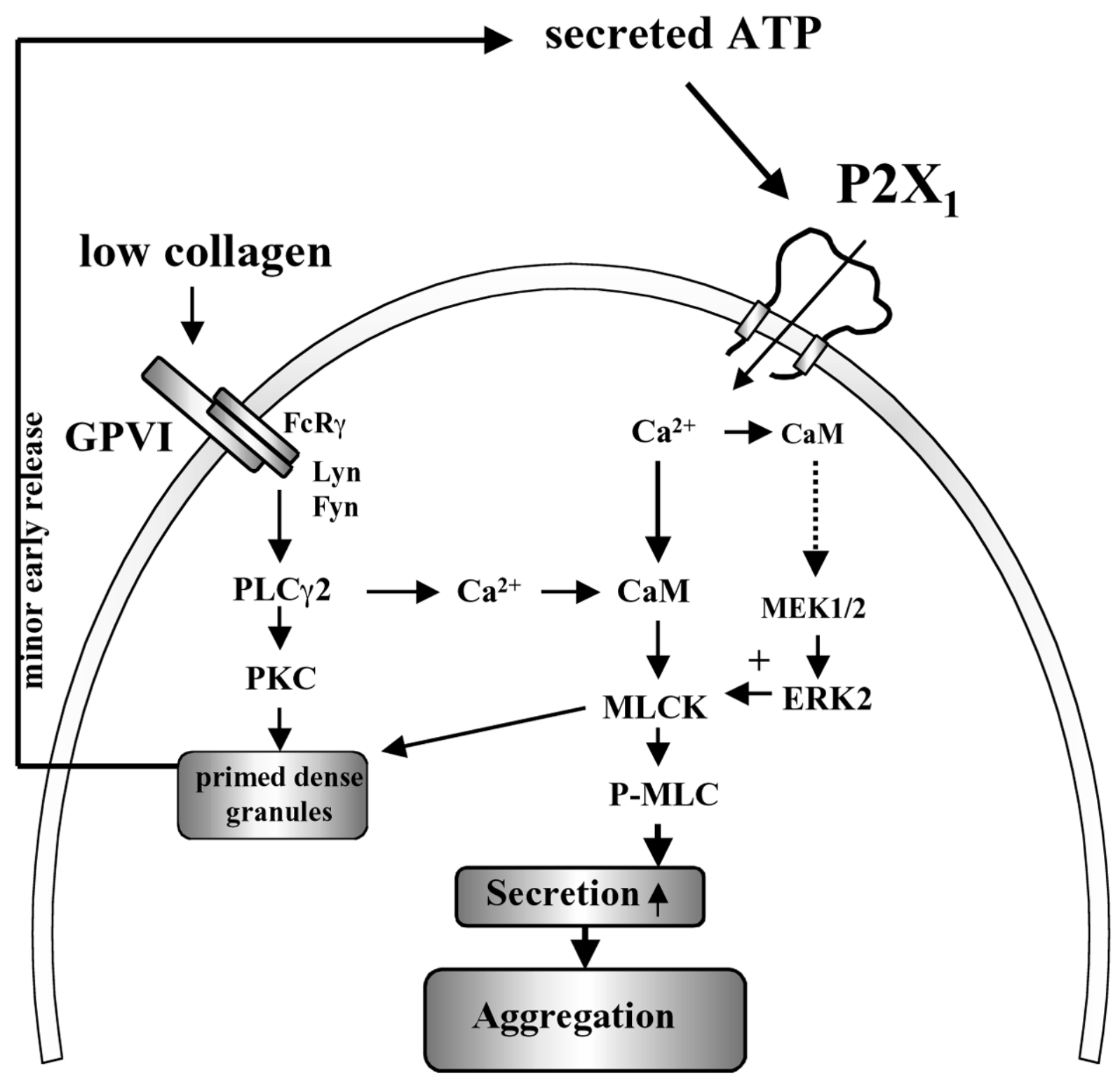

Fig. (4). Model depicting the role of $\mathrm{P}_{2} \mathrm{X}_{1}$ during platelet activation by low doses of collagen. Glycoprotein VI activation by collagen leads

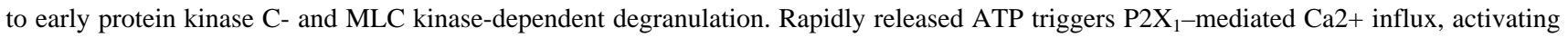
ERK2, in turn amplifying platelet secretion by reinforcing the early MLC kinase activation leading to increased MLC phosphorylation, further granule release and platelet aggregation.

contribution of this receptor to platelet function. Hence, these animal models demonstrate in vivo a role for $\mathrm{P} 2 \mathrm{X}_{1}$ in hemostasis and thrombosis.

Mice overexpressing the platelet $\mathrm{P}_{2} \mathrm{Y}_{1}$ receptor have been generated [152]. Platelets from these mice displayed hyper-reactivity in vitro, as reflected by increased aggregation and induction of the release reaction in response to ADP. Platelet hyper-reactivity was also apparent in vivo: bleeding times were shortened and platelet counts were decreased following infusion of collagen and adrenaline. The increased platelet reactivity of either $\mathrm{P} 2 \mathrm{X}_{1}$ or $\mathrm{P} 2 \mathrm{Y}_{1}$ overexpressing transgenic platelets highlights the positive contribution of both ATP and ADP to platelet activation. In addition, it implies that controlled expression of the $\mathrm{P}_{2} \mathrm{X}_{1}$ and $\mathrm{P} 2 \mathrm{Y}_{1}$ receptor genes is important for normal platelet activation.
Whether variable expression levels of these receptors exist in humans and whether this might play a role in thrombotic states remains to be assessed.

Low concentrations of apyrase (a soluble ATP-diphosphohydrolase (EC 3.6.1.5) catalysing the conversion of ATP into ADP, and ADP into AMP) [153] are widely used during the preparation of washed platelet samples, and it was found to be necessary to preserve $\mathrm{P} 2 \mathrm{Y}_{1}$ receptor functionality during blood handling. More importantly, due to rapid desensitization of $\mathrm{P}_{2} \mathrm{X}_{1}$ by spontaneously released ATP, a high concentration of apyrase is often required to demonstrate $\mathrm{P} 2 \mathrm{X}_{1}$ function. Working with human and murine platelets, the presence of apyrase is necessary to detect $\alpha, \beta-$ meATPinduced $\mathrm{Ca}^{2+}$ influx and platelet shape change. 
Besides this protective function, the presence of apyrase leads to simultaneous degradation of actively secreted ATP and ADP, which interferes with the amplification of ongoing platelet activation, explaining the well-described inhibitory effects of apyrase. Therefore, the use of apyrase for in vitro studies always constitutes a compromise between receptor protection and simultaneous ligand breakdown.

In vivo experiments in mouse models, where endogenous ecto-ATPases prevent receptor desensitization, are thus necessary to confirm the conclusions of the in vitro analyses and to demonstrate a physiological role for platelet $\mathrm{P} 2$ receptors.

This point is even more important if we consider that already nanomolar ATP concentrations can obscure $\mathrm{P} 2 \mathrm{X}_{1}$ receptor responses by driving a significant fraction of the receptor pool into a long-lasting refractory closed state [118, 123]. Thus, we must keep in mind that $\mathrm{P}_{2} \mathrm{X}_{1}$-mediated responses studied in vitro may not reflect correctly the in vivo situation.

\section{CONCLUSIONS}

Over the last eight years, the identification and detailed characterization of the platelet $\mathrm{P} 2 \mathrm{Y}$ receptors for ADP have revealed new targets for the development of antithrombotic drugs. Whether the $\mathrm{P} 2 \mathrm{X}_{1}$ receptor represents a potential target for antithrombotic therapy remains an open question. Even though compounds like MRS2159 has shown some efficacy to selectively antagonize $\mathrm{P} 2 \mathrm{X}_{1}$ in washed human platelet suspensions, the ability of most available P2Xsubtype selective antagonists to inhibit platelet function has still to be defined.

Mice deficient for the three P2 receptors identified on platelets as well as transgenic mice overexpressing platelet $\mathrm{P} 2 \mathrm{X}_{1}$ and $\mathrm{P} 2 \mathrm{Y}_{1}$ receptors now exist. The combined analyses of these animal models should help to further understand how $\mathrm{P} 2 \mathrm{X}$ and $\mathrm{P} 2 \mathrm{Y}$ receptors contribute to platelet function in vivo, and should provide insights on the physiological action of ATP versus ADP at these receptors.

\section{ACKNOLEDGEMENTS}

C.O. is holder of a postdoctoral research mandate of the FWO. Financial support was obtained from the bilateral scientific and technological cooperation between Flanders and Hungary (BIL00/12) and from the FWO project G.0227.03. $\mathrm{J} . \mathrm{V}$. is holder of the Aventis chair of hemostasis research.

\section{ABBREVIATIONS}

$$
\begin{array}{ll}
\alpha, \beta \text {-meATP } & \alpha, \beta \text {-methylene ATP } \\
\beta, \gamma \text {-meATP } & =\beta, \gamma \text {-methylene ATP } \\
\text { ERK } & =\text { Extracellular signal-regulated kinase } \\
\text { MAPK } & =\text { Mitogen-activated protein kinase } \\
\text { 2MeS-ADP } & =2 \text {-methylthio-ADP } \\
\text { MLCK } & =\text { Myosin light chain kinase } \\
\text { PI-3K } & =\text { Phosphoinositide 3-kinase } \\
\text { PLC } & =\text { Phospholipase C } \\
\text { PPADS } & =\text { Pyridoxal-5' -phosphate 6-azophenyl-2', 5' - }
\end{array}
$$

TF

$=$ Tissue factor

VWF

$=$ Von Willebrand factor

\section{REFERENCES}

[1] Born GV. Aggregation of blood platelets by adenosine diphosphate and its reversal. Nature 1962; 194: 927-929.

[2] Gordon J. Extracellular ATP: effects, sources and fates. Biochem J 1986; 233: 309-319.

[3] Oxhorn BC, Cheek DJ, Buxton IL. Role of nucleotides and nucleosides in the regulation of cardiac blood flow. AACN Clin Issues 2000; 11: 241-251.

[4] Bodin P, Burnstock G. Purinergic signaling: ATP release. Neurochem Res 2001; 26: 959-969.

[5] Burnstock G. Purinergic nerves. Pharmacol Rev 1972; 24: 509-581.

[6] Ravelic V, Burnstock G. Receptors for purines and pyrimidines. Pharmacol Rev 1998; 50: 413-492.

[7] Burnstock G, Coks C, Kasakov L, Wong HK. Direct evidence for ATP release from non-adrenergic, non-cholinergic (purinergic) nerves in the guinea-pig taenia coli and bladder. Eur J Pharmacol 1978; 49: 145-149.

[8] Abbracchio MP, Burnstock G. Purinoceptors: are there families of P2X and P2Y purinoceptors ? Pharmacol Ther 1994; 64: 445-475.

[9] Fredholm BB, Abbracchio MP, Burnstock G, Dubyak GR, Harden TK, Jacobson KA, et al. Towards a revised nomenclature for P1 and P2 receptors. Trends in Pharmacol Sci 1997; 18: 79-82.

[10] Khakh BS, Burnstock G, Kennedy C, King BF, North RA, Seguela $\mathrm{P}$, et al. International union of pharmacology. XXIV. Current status of the nomenclature and properties of $\mathrm{P} 2 \mathrm{X}$ receptors and their subunits. Pharmacol Rev 2001; 53: 107-118.

[11] Harden TK, Nicholas RA, Schachter JB, Lazarowski ER, Boyer JL. In: Turner JT, Weisman GA, Fedan JS Ed, The P2 nucleotide receptors.Humana, Totowa. 1998; 109-134.

[12] Léon C, Hechler B, Vial C, Leray C, Cazenave J-P, Gachet C. The $\mathrm{P}_{2} \mathrm{Y}_{1}$ receptor is an ADP receptor antagonized by ATP and expressed in platelets and megakaryoblastic cells. FEBS lett 1997; 403: 26-30.

[13] Mahaut-Smith MP, Ennion SJ, Rolf MG, Evans RJ. ADP is not an agonist at $\mathrm{P} 2 \mathrm{X}_{1}$ receptors: evidence for separate receptors stimulated by ATP and ADP on human platelets. Br J Pharmacol 2000; 131: 108-115.

[14] Mills DCB. ADP receptors in platelets. Thromb Haemost 1996; 76 : 835-856.

[15] Gachet C. ADP receptors of platelets and their inhibition. Thromb Haemost. 2001; 86: 222-232.

[16] Cattaneo M, Gachet C, Cazenave JP, Packham MA. Adenosine diphosphate (ADP) does not induce thromboxane $\mathrm{A}_{2}$ generation in human platelets. Blood 2002; 99: 3868-3869.

[17] Kunapuli SP. Multiple P2 receptor subtypes on platelets: a new interpretation of their function. Trends Pharmacol Sci 1998; 19: 391-394.

[18] Hourani SMO, Hall DA. Receptors for ADP on human platelets. Trends in Pharmacol Sci 1994: 15: 103-108.

[19] Kunapuli SP. Molecular physiology of platelet ADP receptors. Drug Development Research 1998; 45: 135-139.

[20] Daniel JL, Dangelmaier C, Jin J, Ashby B, Smith JB, Kunapuli SP. Molecular basis for ADP-induced platelet activation: evidence for three distinct ADP receptors on platelets. J Biol Chem 1998; 273 : 2024-2029.

[21] Jin J, Kunapuli SP. Co-activation of two different G proteincoupled receptors is essential for ADP-induced platelet aggregation. Proc Natl Acad Sci USA 1998; 95: 8070-8074.

[22] Eckly A, Gendrault JL, Hechler B, Cazenave J-P, Gachet C. Differential involvement of the $\mathrm{P} 2 \mathrm{Y}_{1}$ and $\mathrm{P} 2 \mathrm{Y}_{\mathrm{T}}$ receptors in the morphological changes of platelet aggregation. Thromb Haemost 2001; 85: 694-701.

[23] Park HS, Hourani SM. Differential effects of adenine nucleotide analogues on shape change and aggregation induced by adnosine 5diphosphate (ADP) in human platelets $\mathrm{Br} \mathrm{J}$ Pharmacol 1999;127:1359-1366.

[24] Klages B, Brandt U, Simon MI, Schultz G, Offermanns S. Activation of $G_{12} / G_{13}$ results in shape change and Rho/Rho-kinase- 
mediated myosin light chain phosphorylation in mouse platelets. J Cell Biol 1999; 144: 745-754.

[25] Paul BZ, Daniel JL, Kunapuli SP. Platelet shape change is mediated by both calcium-dependent and -independent signaling pathways. Role of p160 Rho-associated coiled-coil-containing protein kinase in platelet shape change. J Biol Chem 1999; 274: 28293300 .

[26] Dangelmaier C, Jin J, Daniel JL, Smith JB, Kunapuli SP. The P2Y1 receptor mediates ADP-induced p38 kinase-activating factor generation in human platelets. Eur J Biochem 2000; 267: 2283-2289.

[27] Hollopeter J, Jantzen H-M, Vincent D, Li G, England L, Ramakrishnan V, et al. Identification of the platelet ADP receptor targeted by antithrombotic drugs. Nature 2001; 409: 202-207.

[28] Cattaneo M, Lombardi R, Zighetti ML, Gachet C, Ohlmann P, Cazenave JP. Deficiency of $\left({ }^{33} \mathrm{P}\right) 2 \mathrm{MeS}-\mathrm{ADP}$ binding sites on platelets with secretion defect, normal granule stores and normal thromboxane $\mathrm{A}_{2}$ production: evidence that ADP potentiates platelet secretion independently of the formation of large platelet aggregates and thromboxane $\mathrm{A}_{2}$ production. Thromb Haemost 1997; 77 : 986-990.

[29] Cattaneo M, Lecchi A, Lombardi R, Gachet C, Zighetti ML. Platelets from a patient heterozygous for the defect of $\mathrm{P} 2_{\mathrm{CYC}}$ receptors for ADP have a secretion defect despite normal thromboxane $\mathrm{A}_{2}$ production and normal granule stores: further evidence that some cases of platelet primary secretion defect are heterozygous for a defect of $\mathrm{P} 2_{\text {CYC }}$ receptors. Arterioscl Thromb vasc Biol 2000; 20: E101-106.

[30] Trumel C, Payrastre B, Plantavid M, Hechler B, Vial C, Presek P, et al. A key role for adenosine diphosphate in the irreversible platelet aggregation induced by the PAR1-activating peptide through the late activation of phosphoinositide 3-kinase. Blood 1999; 94: 4156-4165.

[31] Kim S, Foster C, Lecchi A, Quinton TM, Prosser DM, Jin J, et al. Protease-activated receptors 1 and 4 do not stimulate $G_{i}$ signaling pathways in the absence of secreted ADP and cause human platelet aggregation independently of $\mathrm{G}_{\mathrm{i}}$ signaling. Blood 2002; 99: 36293636.

[32] Léon C, Vial C, Gachet C, Ohlmann P, Hechler B, Cazenave J-P, et $a l$. The $\mathrm{P} 2 \mathrm{Y}_{12}$ receptor is normal in a patient presenting a severe deficiency of ADP-induced platelet aggregation: further evidence for a distinct P2 receptor responsible for adenylyl cyclase inhibition. Thromb Haemost 1999; 81: 775-781.

[33] Fabre JE, Nguyen M, Latour A, Keifer JA, Audoly LP, Coffman $\mathrm{TM}$, et al. Decreased platelet aggregation, increased bleeding time and resistance to thromboembolism in $\mathrm{P}_{2} \mathrm{Y}_{1}$-deficient mice. Nat Med 1999; 5: 1199-1202.

[34] Léon C, Hechler B, Freund M, Eckly A, Vial C, Ohlmann P, et al. Defective platelet aggregation and increased resistance to thrombosis in purinergic $\mathrm{P}_{2} \mathrm{Y}_{1}$ receptor-null mice. J Clin Invest 1999; 104: 1731-1737.

[35] Nieswandt B, Schulte V, Zywietz A, Gratacap MP, Offermans S. Costimulation of $\mathrm{G}_{\mathrm{i}^{-}}$and $\mathrm{G}_{12} / \mathrm{G}_{13}$ signaling pathways induces integrin $\alpha_{\mathrm{IIb}} \beta_{3}$ activation in platelets. J Biol Chem 2002; 277: 3949339498.

[36] Kauffenstein G, Bergmeier W, Eckly A, Ohlmann P, Léon C, Cazenave J-P, et al. The $\mathrm{P} 2 \mathrm{Y}_{12}$ receptor induces platelet aggregation through weak activation of the $\alpha_{\mathrm{IIb}} \beta_{3}$ integrin-a phosphoinositide 3-kinase-dependent mechanism. FEBS lett 2001; 505: 281290.

[37] Woulfe D, Jiang H, Mortensen R, Yang J, Brass LF. Activation of Rap1B by Gi family members in platelets. J Biol Chem 2002; 277: 23382-23390.

[38] Larson MK, Chen H, Kahn ML, Taylor AM, Fabre JE, Mortensen $\mathrm{RM}$, et al. Identification of $\mathrm{P}_{2} \mathrm{Y}_{12}$-dependent and -independent mechanisms of glycoprotein VI-mediated Rap1 activation in platelets. Blood 2003; 101: 1409-1415.

[39] Dangelmaier C, Jin J, Smith JB, Kunapuli SP. Potentiation of thromboxane $\mathrm{A}_{2}$-induced platelet secretion by $\mathrm{Gi}$ signaling through the phosphoinositide-3 kinase pathway. Thromb Haemost 2001; 85: 341-348.

[40] Kim S, Jin J, Kunapuli SP. Akt activation in platelets depends on Gi signaling pathways. J Biol Chem, in press.

[41] Hourani SMO. Pharmacology of the platelet ADP receptors:agonists and antagonists. Haematologica 2000; 85: 58-65.
[42] Nurden P, Savi P, Heilmann E, Bihour C, Herbert J-M, Maffrand J$\mathrm{P}$, et al. An inherited bleeding disorder linked to a defective interaction between ADP and its receptor on platelets. J Clin Invest 1995; 95: 1612-1621.

[43] Gachet C, Cattaneo M, Ohlmann P, et al. Purinoceptors on blood platelets: further pharmacological and clinical evidence to suggest the presence of two ADP receptors. Br J Haematol 1995; 91: 434444.

[44] Savi P, Beauverger P, Labouret C, . Role of $\mathrm{P}_{2} \mathrm{Y}_{1}$ purinoceptor in ADP-induced platelet activation. FEBS lett 1998; 422: 291-295.

[45] Foster CJ, Prosser DM, Agans JM, Zhai Y, Smith MD, Lachowicz $\mathrm{JE}$, et al. Molecular identification and characterization of the platelet ADP receptor targeted by thienopyridine antithrombotic drugs. J Clin Invest 2001; 107: 1591-1598.

[46] Nurden P, Poujol C, Winckler J, Combrie R, Pousseau N, Conley $\mathrm{PB}$, et al. Immunolocalization of $\mathrm{P} 2 \mathrm{Y}_{1}$ and TPalpha receptors in platelets showed a major pool associated with the membranes of alpha-granules and the open canalicular system. Blood 2003; 101: 1400-1408.

[47] Baurand A, Eckly A, Bari N, Leon C, Hechler B, Cazenave JP, Gachet C. Desensitization of the platelet aggregation response to ADP: differential down-regulation of the $\mathrm{P} 2 \mathrm{Y}_{1}$ and $\mathrm{P} 2$ cyc receptors. Thromb Haemost. 2000; 84: 484-91.

[48] Webb TE, Simon J, Krishek BJ, Bateson AN, Smart TG, King BF, et al. Cloning and functional expression of a brain G-proteincoupled ATP receptor. FEBS lett 1993; 324: 219-225.

[49] King BF, Burnstock G, Boyer JL, Boeynaems J-M, Weisman GA, Kennedy C, et al. In: IUPHAR Compendium of receptor characterization and classification, $2^{\text {nd }}$ ed. P2Y receptors. 2001; 306-320.

[50] Communi D, Gonzalez NS, Detheux M, Brezillon S, Lannoy V, Parmentier M, et al. Identification of a novel human ADP receptor coupled to Gi. J Biol Chem 2001; 276: 41479-41485.

[51] Léon C, Freund M, Ravanat C, Baurand A, Cazenave JP, Gachet C. Key role of the $\mathrm{P}_{2} \mathrm{Y}_{1}$ receptor in tissue factor-induced thrombindependent acute thromboembolism: studies in $\mathrm{P}_{2} \mathrm{Y}_{1}$-knockout mice and mice treated with a $\mathrm{P} 2 \mathrm{Y}_{1}$ antagonist. Circulation 2001; 103 : 718-723.

[52] Boyer JL, Adams M, Ravi RG, Jacobson KA, Harden TK. 2Chloro- $N^{6}$-methyl- $(N)$-methanocarba-2'-deoxyadenosine-3', 5' biphosphate is a selective high affinity $\mathrm{P} 2 \mathrm{Y}_{1}$ receptor antagonist. $\mathrm{Br}$ J Pharmacol 2002; 135: 2004-2010.

[53] Waldo GL, Corbitt J, Boyer JL, Ravi G, Kim HS, Ji XD, et al. Quantitation of the $\mathrm{P} 2 \mathrm{Y}_{1}$ receptor with a high affinity radiolabelled antagonist. Mol Pharmacol 2002; 62: 1249-1257.

[54] Boyer JL, Romero-Avila T, Schachter JB, Harden TK. Identification of competitive antagonists of the $\mathrm{P}_{2} \mathrm{Y}_{1}$ receptor. Mol Pharmacol 1996; 50: 1323-1329.

[55] Bultmann R, Tuluc F, Starke K. On the suitability of adenosine 3'phosphate 5'-phosphosulfate as a selective $\mathrm{P} 2 \mathrm{Y}$ receptor antagonist in intact tissue. Eur J Pharmacol 1998; 351: 209-215.

[56] Toth-Zsamboki E, Oury C, Tytgat J, Vermylen J, Hoylaerts MF. The $\mathrm{P} 2 \mathrm{Y}_{1}$ receptor antagonist adenosine-2'-phosphate-5' -phosphate non-selectively antagonizes the platelet $\mathrm{P} 2 \mathrm{X}_{1}$ ion channel. Thromb Haemost 2001; 86: 1338-1339.

[57] Boyer JL, Mohanram A, Camaioni E, Jacobson KA, Harden TK. Competitive and selective antagonism of $\mathrm{P} 2 \mathrm{Y}_{1}$ receptors by $\mathrm{N}^{6}$ methyl 2'-deoxyadenosine 3', 5'-biphosphate. Br J Pharmacol 1998; 124: 1-3.

[58] Baurand A, Gachet C. The $\mathrm{P} 2 \mathrm{Y}_{1}$ Receptor as a Target for New Antithrombotic Drugs: A Review of the P2Y ${ }_{1}$ Antagonist MRS2179. Cardiovasc Drug Rev 2003; 21: 67-76.

[59] Baurand A, Raboisson P, Freund M, Léon C, Cazenave J-P, Bourguignon JJ, Gachet C. Inhibition of platelet function by administration of MRS2179, a $\mathrm{P}_{2} \mathrm{Y}_{1}$ receptor antagonist. Eur J Pharmacol 2001; 412: 213-221.

[60] Lenain N, Freund M, Leon C, Cazenave JP, Gachet C. Inhibition of localized thrombosis in P2Y1-deficient mice and rodents treated with MRS2179, a P2Y1 receptor antagonist. J Thromb Haemost. 2003; 1: 1144-9.

[61] Brown SG, King BF, Kim YC, Jang SY, Burnstock G, Jacobson KA. Activity of novel adenine nucleotide derivatives as agonists and antagonists at recombinant rat P2X receptors. Drug Dev Res 2000; 49: 253-259. 
[62] Ayyanathan K, Webb TE, Sandhu AK, Athwal RS, Barnard EA, Kunapuli SP. Cloning and chromosomal localization of the human $\mathrm{P}_{2} \mathrm{Y}_{1}$ purinoceptor. Biochem Biophys Res Comm 1996; 22: 419424.

[63] Zhang FL, Luo L, Gustafson E, Lachowicz J, Smith M, Qiao X, et $a l$. ADP is the cognate ligand for the orphan G-protein coupled receptor SP1999. J Biol Chem 2001; 276: 8608-8615.

[64] Ayyanathan K, Naylor SL, Kunapuli SP. Structural characterization and fine chromosomal mapping of the human $\mathrm{P}_{2} \mathrm{Y}_{1}$ purinergic receptor gene. Som Cell Mol Genet 1996; 22: 419-424.

[65] Kam PC, Nethery CM. The thienopyridines derivatives (platelet adenosine diphosphate receptor antagonists), pharmacology and clinical developments. Anaesthesia 2003; 58: 28-35.

[66] Seyfarth HJ, Koksh M, Roethig G, Rother T, Neugebauer A, Klein $\mathrm{N}$, et al. Effect of 300- and 450-mg clopidogrel loading doses on membrane and soluble P-selectin in patients undergoing coronary stent implantation. Am Heart J 2002; 143: 118-123.

[67] Herbert J-M, Frehel D, Bernat A, Badorc A, Savi P, Delebassée D, et al. Clopidogrel hydrogenosulfate. Drug Future 1993; 18: 107112.

[68] Geiger J, Brich J, Honig-Liedl P, Eigenthaler M, Schanzenbacher $\mathrm{P}$, Herbert J-M, et al. Specific impairment of human platelet $\mathrm{P} 2 \mathrm{Y}_{\mathrm{AC}}$ ADP receptor-mediated signaling by the antiplatelet drug clopidogrel. Arterioscl Thromb Vasc Biol 1999; 19: 2007-2011.

[69] Savi P, Labouret C, Delesque N, Guette F, Lupker J, Herbert JM. $\mathrm{P}_{2} \mathrm{Y}_{12}$, a new platelet ADP receptor, target of clopidogrel. Biochem Biophys Res Comm 2001; 283: 379-383.

[70] Savi P, Laplace MC, Maffrand JP, Herbert J-M. Binding of $\left[{ }^{3} \mathrm{H}\right]-2-$ methylthio ADP to rat platelets: effect of clopidogrel and ticlopidine. J Pharmacol Exp Ther 1994; 269: 772-777.

[71] Savi P, Herbert J-M, Pflieger AM, Dol F, Delebassée D, Combalbert $\mathrm{J}$, et al. Importance of hepatic metabolism in the antiaggregating activity of the thienopyridine clopidogrel. Biochem Pharmacol 1992; 44: 527-532.

[72] Savi P, Combalbert J, Gaich C, Rouchon MC, Maffrand JP, Berger $\mathrm{Y}$, et al. The antiaggregating activity of clopidogrel is due to a metabolic activation by hepatic cytochrome P450-1A. Thromb Haemost 1994; 72: 313-317.

[73] Savi P, Pereillo JM, Uzabiaga MF, Combalbert J, Picard C, Maffrand JP", et al. Identification and biological activity of the active metabolite of clopidogrel. Thromb Haemost 2000; 84: 891-896.

[74] Pereillo J-M, Maftouh M, Andrieu A, Uzabiaga M-F, Fedeli O, Savi $\mathrm{P}$, et al. Structure and stereochemistry of the active metabolite of clopidogrel. Drug Metabolism Disposition 2002; 30: 1288-1295.

[75] Bennett JS. Novel platelet inhibitors. Annu Rev Med 2001; 52: 161-184.

[76] Sugidachi A, Asai F, Ogawa T, Inoue T, Koike H. The in vivo pharmacological profile of CS-747, a novel antiplatelet agent with platelet ADP receptor antagonist properties. Br J Pharmacol 2000; 129: 1439-1446.

[77] Sugidachi A, Asai F, Yoneda K, Iwamura R, Ogawa T, Otsuguro $\mathrm{K}$, et al. Antiplatelet action of R-99224, an active metabolite of a novel thienopyridine-type G(i)-linked P2T antagonist, CS-747. Br J Pharmacol 2001; 132: 47-54.

[78] Rao AK, Kowalska MA. ADP-induced platelet shape change and mobilization of cytoplasmic ionized calcium are mediated by distinct binding sites on platelets: 5'-p-fluorosulfonyl benzoyladenosine is a weak platelet agonist. Blood 1987; 70: 751-756.

[79] Ding Z, Kim S, Dorsam RT, Jin J, Kunapuli SP. Inactivation of the human $\mathrm{P} 2 \mathrm{Y}_{12}$ receptor by thiol reagents requires interaction with both extracellular cysteine residues, $\mathrm{C} 17$ and $\mathrm{C} 270$. Blood, in press.

[80] Ingall AH, Dixon J, Bailey A, Coombs ME, Cox D, McInally JI, et al. Antagonists of the platelet $\mathrm{P} 2 \mathrm{~T}$ receptor: a novel approach to antithrombotic therapy. J Med Chem 1999; 42: 213-220.

[81] Humphries RG. Pharmacology of AR-C69931-MX and related compounds: from pharmacological tools to clinical trials. Haematologica 2000; 85: 66-72.

[82] Huang J, Discroll EM, Gonzales ML, Park AM, Lucchesi BR. Prevention of arterial thrombosis by intravenously administered platelet P2T receptor antagonist AR-C69931MX in a canine model. J Pharmacol Exp Ther 2000; 295: 492-499.

[83] Wang K, Zhou X, Zhou Z, Tarakaji K, Carneiro M, Penn MS, et al. Blockade of the platelet $\mathrm{P} 2 \mathrm{Y}_{12}$ receptor by AR-C69931MX sustains coronary artery recanalization and improves the myocardial tissue perfusion in a canine thrombosis model. Arterioscl Thromb Vasc Biol 2003; 23: 357-362.

[84] Cattaneo M, Lecchi A, Randi AM, Mc Gregor JL, Mannucci PM. Identification of a new congenital defect of platelet aggregation characterized by severe impairment of platelet responses to adenosine 5'-diphosphate. Blood 1992; 80: 2787-2796.

[85] Cattaneo M, Zighetti ML, Lombardi R, Martinez C, Lecchi A, Conley PB, et al. Molecular bases of defective signal transduction in the platelet $\mathrm{P} 2 \mathrm{Y}_{12}$ receptor of a patient with congenital bleeding. Proc Natl Acad Sci USA 2003; 100: 1978-1983.

[86] Cattaneo M, Gachet C. ADP receptors and clinical bleeding disorders. Arterioscler Thromb Vasc Biol 1999; 19: 2281-5.

[87] Leon C, Ravanat C, Freund M, Cazenave JP, Gachet C. Differential involvement of the $\mathrm{P} 2 \mathrm{Y} 1$ and $\mathrm{P} 2 \mathrm{Y} 12$ receptors in platelet procoagulant activity. Arterioscler Thromb Vasc Biol. 2003; 23: 1941-7.

[88] Leon C, Alex M, Klocke A, Morgenstern E, Moosbauer C, Eckly A, Spannagl M, Gachet C, Engelmann B. Platelet ADP receptors contribute to the initiation of intravascular coagulation. Blood. 2004; 103: 594-600.

[89] Buell G, Collo G, Rassendren F. P2X receptors: an emerging channel family. Eur J Neurosci. 1996;8:2221-2228.

[90] North RA. Molecular physiology of P2X receptors. Physiol Rev. 2002; 82: 1013-1067.

[91] Newbolt A, Stoop R, Virginio c, Surprenant A, North RA, Buell G, Rassendren F. Membrane topology of an ATP-gated ion channel (P2X receptor). J Biol Chem 1998; 273: 15177-15182.

[92] Torres GE, Egan TM, Voigt MM. N-linked glycosilation is essential for the functional expression of the recombinant $\mathrm{P} 2 \mathrm{X}_{2}$ receptor. Biochemistry 1998;37: 4845-4851.

[93] Kim M, Jiang LH, Wilson HL, North RA, Surprenant A. Proteomic and functional evidence for a $\mathrm{P} 2 \mathrm{X}_{7}$ receptor signalling complex. EMBO J 2001; 20: 6347-6358.

[94] Jiang LH, Kim M, Spelta V, Bo X, Surprenant A, North RA. Subunit arrangement in P2X receptors. J Neurosci. 2003; 23: 890310 .

[95] Kim M, Yoo OJ, Choe S. Molecular assembly of the extracellular domain of $\mathrm{P}_{2} \mathrm{X}_{2}$, an ATP-gated ion channel. Biochem Biophys Res Comm 1997; 240: 618-622.

[96] Ennion S, Hagan S, Evans RJ. The role of positively charged amino

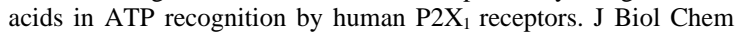
2000; 275: 29361-29367.

[97] Roberts JA, Evans RJ. ATP binding at human P2X1 receptors; contribution of aromatic and basic amino acids revealed using mutagenesis and partial agonists. J Biol Chem, in press.

[98] Robertson SJ, Ennion SJ, Evans RJ, Edwards FA. Synaptic P2X receptors. Curr Opin Neurobiol 2001; 11: 378-386.

[99] Buell G, Lewis C, Collo G; An antagonist-insensitive P2X receptor expressed in epithelia and brain. EMBO J 1996; 15: 55-62.

[100] Werner P, Seward EP, Buell G, North RA. Domains of P2X receptors involved in desensitization. Proc Natl Acad Sci USA 1996; 93: $15485-15490$.

[101] Rettinger J, Schmalzing G. Desensitization masks nanomolar potency of ATP at the $\mathrm{P} 2 \mathrm{X} 1$ receptor. J Biol Chem, in press.

[102] King B, Chen CC, Akopian AN, Burnstock G, Wood JN. A role for calcineurin in the desensitization of the $\mathrm{P}_{2} \mathrm{X}_{3}$ receptor. Neuroreport 1997; 8: 1099-1102.

[103] Dutton JL, Poronnik P, Li GH, Holding CA, Worthington RA, Vandenberg RJ, et al. $\mathrm{P} 2 \mathrm{X}_{1}$ receptor membrane redistribution and downregulation visualized by using receptor-coupled green fluorescent protein chimeras. Neuropharmacology 2000; 39: 20542066.

[104] Ennion SJ, Evans RJ. Agonist-stimulated internalization of the ligand-gated ion channel $\mathrm{P}_{2} \mathrm{X}_{1}$ in rat vas deferens. FEBS lett 2001; 489: 154-158.

[105] Boue-Grabot E, Archambault V, Seguela P. A protein kinase C site highly conserved in $\mathrm{P} 2 \mathrm{X}$ subunits controls the desensitization kinetics of $\mathrm{P} 2 \mathrm{X}_{2}$ ATP-gated channels. J Biol Chem 2000; 275: 10190-10195.

[106] Paukert M, Osteroth R, Geisler HS, Braendle U, Glowatzki E, Ruppersberg JP, et al. Inflammatory mediators potentiate ATPgated channels through the $\mathrm{P}_{2} \mathrm{X}_{3}$ subunit. J Biol Chem 2001; 276 : 21077-21082. 
[107] Liu GJ, Brockhausen J, Bennett MR. P2X1 receptor currents after disruption of the PKC site and its surroundings by dominant negative mutations in HEK293 cells. Auton Neurosci. 2003; 108: 12-6.

[108] Toth-Zsamboki E, Oury C, Watanabe H, Nilius B, Vermylen J, Hoylaerts MF. The intracellular tyrosine residues of the ATP-gated $\mathrm{P} 2 \mathrm{X}_{1}$ ion channel are essential for its function. FEBS lett 2002; 524: 15-19.

[109] Evans RJ, Lewis C, Virginio C, Lundstrom K, Buell G, Surprenant A, et al. Ionic permeability of, and divalent cation effects on, two ATP-gated cation channels (P2X receptors) expressed in mammalian cells. J Physiol 1996; 497: 413-422.

[110] King BF, Wildman SS, Ziganshina LE, Pintor J, Burnstock G; Effects of extracellular $\mathrm{pH}$ on agonism and antagonism at a recombinant $\mathrm{P}_{2} \mathrm{X}_{2}$ receptor. Br J Pharmacol 1997; 121: 1445-1453.

[111] Valera S, Hussy N, Evans RJ. A new class of ligand-gated ion channel defined by P2X receptor for extracellular ATP. Nature 1994; 371: 516-519.

[112] Valera S, Talabot F, Evans RJ. Characterization and chromosomal localization of a human $\mathrm{P} 2 \mathrm{X}_{1}$ receptor from the urinary bladder. Recept Channel 1995; 3: 283-289.

[113] Dhulipala PDK, Lianos EA, Kotlikoff MI. Regulation of human $\mathrm{P} 2 \mathrm{X}_{1}$ promoter activity by beta helix-loop-helix factors in smooth muscle cells. Gene 2001; 269: 167-175.

[114] Virginio C, Robertson G, Surprenant A, Trinitrophenyl-substituted nucleotides are potent antagonists selective for $\mathrm{P} 2 \mathrm{X}_{1}, \mathrm{P} 2 \mathrm{X}_{3}$, and heteromeric $\mathrm{P} 2 \mathrm{X}_{2 / 3}$ receptors. Mol Pharmacol 1998; 53: 969-973.

[115] Soto F, Lambrecht G, Nickel P, Stuhmer W, Busch AE. Antagonistic properties of the suramin analogue NF023 at heterologously expressed P2X receptors. Neuropharmacology 1999; 38: 141-149.

[116] Klapperstuck M, Buttner C, Nickel P, Schmalzing G, Lambrecht G, Markwardt F. Antagonism by the suramin analogue NF279 on human $\mathrm{P} 2 \mathrm{X}_{1}$ and $\mathrm{P} 2 \mathrm{X}_{7}$ receptors. Eur J Pharmacol 2000; 387: 245252.

[117] Inscho EW, Cook AK, Imig JD, Vial C, Evans RJ. Physiological role for $\mathrm{P} 2 \mathrm{X} 1$ receptors in renal microvascular autoregulatory behavior. J Clin Invest 2003;112: 1895-905.

[118] Rettinger J, Schmalzing G, Damer S, Muller G, Nickel P, Lambrecht G. The suramin analogue NF279 is a novel and potent antagonist selective for the $\mathrm{P}_{2} \mathrm{X}_{1}$ receptor. Neuropharmacology 2000; 39: 2044-53.

[119] Hulsmann M, Nickel P, Kassack M, Schmalzing G, Lambrecht G, Markwardt F. NF449, a novel picomolar potency antagonist at human P2X1 receptors. Eur J Pharmacol. 2003; 470: 1-7.

[120] Kim YC, Brown SG, Harden TK, Boyer JL, Dubyak G, King BF, et al. Structure-activity relationships of pyridoxal phosphate derivatives as potent and selective antagonists of $\mathrm{P} 2 \mathrm{X}_{1}$ receptors. $\mathrm{J}$ Med Chem 2001; 44: 340-349.

[121] Evans RJ, Lewis C, Buell G, Valera S, North RA, Surprenant A. Pharmacological characterization of heterologously expressed ATP-gated cation channels (P2X purinoceptors). Mol Pharmacol 1995; 48: 178-183.

[122] Cuzack NJ, Hourani SMO. Some pharmacological and biochemical interactions of the enantiomers of adenylyl 5 '- $\beta, \gamma$-methylenediphosphate with the guinea-pig urinary bladder. Br J Pharmacol 1984; 82: 155-159.

[123] Rettinger J, Schmalzing G. Activation and desensitization of the recombinant $\mathrm{P} 2 \mathrm{X} 1$ receptor at nanomolar ATP concentrations. J Gen Physiol. 2003; 121: 451-61.

[124] Liang SX, Jenkins NA, Gilbert DJ, Copeland NG, Phillips WD. Structure and chromosome location of the mouse P2X(1) purinoceptor gene (P2rx1). Cytogenet Cell Genet. 2001; 92: 333-6.

[125] Mulryan K, Gitterman DP, Lewis CJ, Vial C, Leckie BJ, Cobb AL, Brown JE, Buell G, Pritchard CA, Evans RJ. Reduced vas deferens contraction and male infertility in mice lacking $\mathrm{P} 2 \mathrm{X}_{1}$ receptors. Nature. 2000;403:86-89.

[126] Vial C, Evans RJ. P2X receptor expression in mouse urinary bladder and the requirement of $\mathrm{P} 2 \mathrm{X}(1)$ receptors for functional $\mathrm{P} 2 \mathrm{X}$ receptor responses in the mouse urinary bladder smooth muscle. $\mathrm{Br} \mathrm{J}$ Pharmacol. 2000; 131: 1489-95.

[127] Vial C, Evans RJ. P2X(1) receptor-deficient mice establish the native $\mathrm{P} 2 \mathrm{X}$ receptor and a P2Y6-like receptor in arteries. Mol Pharmacol. 2002; 62: 1438-45.
[128] Vial C, Evans RJ. Smooth muscles does not have a common P2x receptor phenotype: expression, ontogeny and function of $\mathrm{P} 2 \mathrm{x} 1$ receptors in mouse ileum, bladder and reproductive systems. Auton Neurosci. 2001; 92: 56-64.

[129] Calvert JA, Evans RJ. Heterogeneity of P2X Receptors in Sympathetic Neurons: Contribution of Neuronal P2X1 Receptors Revealed Using Knockout Mice. Mol Pharmacol. 2004; 65: 139-48.

[130] Vial C, Hechler B, Léon C, Cazenave J-P, Gachet C. Presence of $\mathrm{P} 2 \mathrm{X}_{1}$ purinoceptors in human platelets and megakaryocytic cell lines. Thromb Haemost 1997; 78: 1500-1504.

[131] Clifford EE, Parker K, Humphreys BD, Kertesy SB, Dubyak GR. The $\mathrm{P} 2 \mathrm{X}_{1}$ receptor, an adenosine triphosphate-gated cation channel, is expressed in human platelets but not in human blood leukocytes. Blood 1998; 91: 3172-3181.

[132] Scase TJ, Heath MF, Allen JM, Sage SO, Evans RJ. identification of a $\mathrm{P} 2 \mathrm{X}_{1}$ purinoceptor expressed on human platelets. Biochem Biophys Res Comm 1998; 242: 525-528.

[133] MacKenzie AB, Mahaut-Smith MP, Sage SO. Activation of receptor-operated cation channels via $\mathrm{P} 2 \mathrm{X} 1$ not $\mathrm{P} 2 \mathrm{~T}$ purinoceptors in human platelets. J Biol Chem. 1996; 271: 2879-81.

[134] Sage SO, MacKenzie AB, Jenner S, Mahaut-Smith MP. Purinoceptor-evoked calcium signalling in human platelets. Prostaglandins Leukot Essent Fatty Acids 1997; 57: 435-438.

[135] Somasundaram B, Mahaut-Smith MP. Three cation influx currents activated by purinergic receptor stimulation in rat megakaryocytes. J Physiol 1994; 480: 225-231.

[136] Mahaut-Smith MP, Ennion SJ, Rolf MG, Evans RJ. ADP is not an agonist at $\mathrm{P} 2 \mathrm{X}_{1}$ receptors: evidence for separate receptors stimulated by ATP and ADP on human platelets. Br J Pharmacol 2000; 131: $108-114$

[137] Oury C, Toth-Zsamboki E, Thys C, Tytgat J, Vermylen J, Hoylaerts MF. The ATP-gated $\mathrm{P}_{2} \mathrm{X}_{1}$ ion channel acts as a positive regulator of platelet responses to collagen. Thromb Haemost 2001; 86: $1264-1271$.

[138] Greco NJ, Tonon G, Chen W, Luo X, Dalal R, Jamieson GA. Novel structurally altered $\mathrm{P}(2 \mathrm{X} 1)$ receptor is preferentially activated by adenosine diphosphate in platelets and megakaryocytic cells. Blood. 2001; 98(1): 100-7.

[139] Oury C, Toth-Zsamboki E, Vermylen J, Hoylaerts MF. Does the $\mathrm{P}(2 \mathrm{X} 1$ del $)$ variant lacking 17 amino acids in its extracellular domain represent a relevant functional ion channel in platelets? Blood. 2002; 99: 2275-7.

[140] Vial C, Pitt SJ, Roberts J, Rolf MG, Mahaut-Smith MP, Evans RJ. Lack of evidence for functional ADP-activated human P2X1 receptors supports a role for ATP during hemostasis and thrombosis. Blood 2003; 102: 3646-51.

[141] Mahaut-Smith MP, Sage SO, Rink TJ. Receptor-activated single channels in intact human platelets. J Biol Chem 1990; 265: 1047910483.

[142] Savi P, Bornia J, Salel V, Delfaud M, Herbert J-M. Characterization of $\mathrm{P} 2 \mathrm{X}_{1}$ purinoreceptors on rat platelets: effect of clopidogrel. B J Haematol 1997; 98: 880-886.

[143] Vial C, Rolf MG, Mahaut-Smith MP, Evans RJ. A study of P2X receptor function in murine megakaryocytes and human platelets reveals synergy with P2Y receptors. Br J Pharmacol 2002; 135: 363-372.

[144] Oury C, Toth-Zsamboki E, Van Geet C, Thys C, Wei L, Nilius B, Vermylen J, Hoylaerts MF. A natural dominant negative $\mathrm{P} 2 \mathrm{X}_{1}$ receptor due to deletion of a single amino acid residue. J Biol Chem 2000; 275: 22611-22614.

[145] Rolf MG, Brearley CA, Mahaut-Smith MP. Platelet shape change evoked by selective activation of $\mathrm{P} 2 \mathrm{X}_{1}$ purinoceptors with $\alpha, \beta$-methylene ATP. Thromb Haemost 2001; 85: 303-8.

[146] Rolf MG, Mahaut-Smith MP. Effects of enhanced $\mathrm{P}_{2} \mathrm{X}_{1}$ receptor $\mathrm{Ca}^{2+}$ influx on functional responses in human platelets. Thromb Haemost 2002; 88: 495-502.

[147] Erhardt JA, Pillarisetti K, Toomey JR. Potentiation of platelet activation through the stimulation of $\mathrm{P} 2 \mathrm{X} 1$ receptors. J Thromb Haemost. 2003; 1: 2626-35.

[148] Oury C, Toth-Zsamboki E, Vermylen J, Hoylaerts MF. P2X ${ }^{-}$ mediated activation of extracellular signal-regulated kinase 2 contributes to platelet secretion and aggregation induced by collagen. Blood. 2002;100:2499-2505. 
[149] Toth-Zsamboki E, Oury C, Cornelissen H, De Vos R, Vermylen J, Hoylaerts MF. P2X1-mediated ERK2 activation amplifies the collagen-induced platelet secretion by enhancing myosin light chain kinase activation. J Biol Chem. 2003; 278: 46661-7.

[150] Oury C, Kuijpers MJE, Toth-Zsamboki, Bonnefoy A, Danloy S, Vreys I, Feijge M, De Vos R, Vermylen J, Heemskerk JWM, Hoylaerts MF. Overexpression of the platelet $\mathrm{P} 2 \mathrm{X}_{1}$ ion channel.in transgenic mice generates a novel prothrombotic phenotype. Blood 2003; 101: 3969-76.
[151] Hechler B, Lenain N, Marchese P, Vial C, Heim V, Freund M, Cazenave JP, Cattaneo M, Ruggeri ZM, Evans R, Gachet C. A role of the fast ATP-gated P2X1 cation channel in thrombosis of small arteries in vivo. J Exp Med. 2003; 198: 661-7.

[152] Hechler B, Zhang Y, Eckly A, Cazenave J-P, Gachet C, Ravid K. Lineage-specific overexpression of the $\mathrm{P} 2 \mathrm{Y}_{1}$ receptor induces platelet hyper-reactivity in transgenic

[153] Handa M, Gudotti G. Purification and cloning of a soluble ATP diphosphohydrolase (apyrase) from potato tubers (Solanum tuberosum). Biochem Biophys Res Comm 1996; 218: 916-923. 